
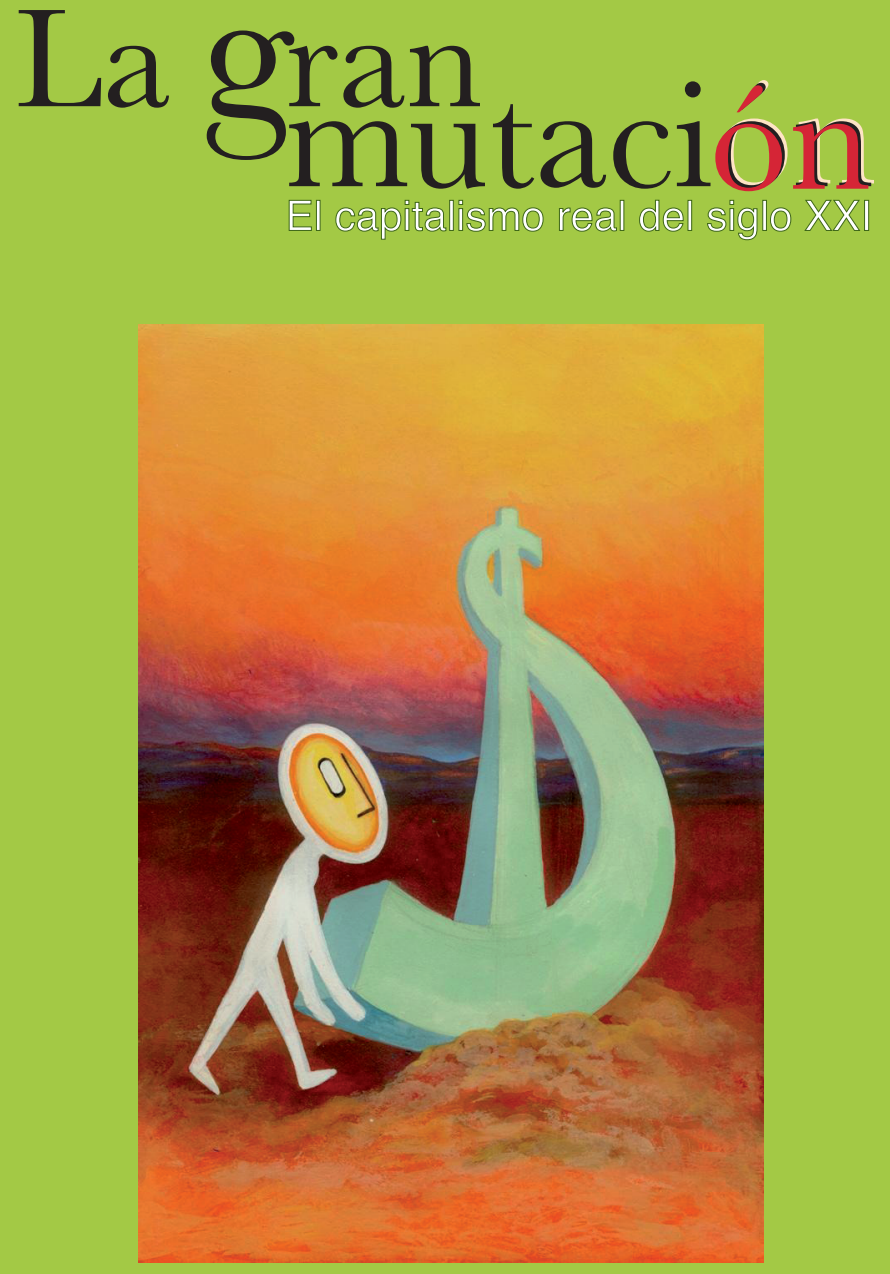

$\frac{4}{8}$

y

ㄴ.

$\frac{2}{2}$

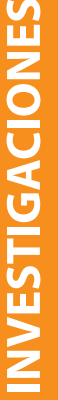

4

$\underline{4}$

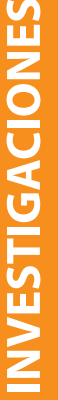

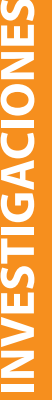

H

11
$\frac{1}{2}$
$\frac{1}{6}$
$\frac{1}{2}$
$z$

불

e

$\frac{9}{\alpha+2}$

,

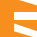

,

$\frac{1}{9}$

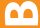

Oscar Ugarteche • Eduardo Martínez-Ávila 


\section{LA GRAN MUTACIÓN}

El capitalismo real del siglo XXI 


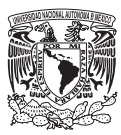

UNIVERSIDAD NACIONAL AUTÓNOMA DE MÉXICO

Dr. José Narro Robles

Rector

Dr. Eduardo Bárzana García

Secretario General

Ing. Leopoldo Silva Gutiérrez

Secretario Administrativo

Dra. Estela Morales Campos

Coordinadora de Humanidades

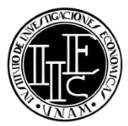

INSTITUTO DE INVESTIGACIONES ECONÓMICAS

Dra. Verónica Villarespe Reyes

Directora

Mtro. Gustavo López Pardo

Secretario Académico

Aristeo Tovías García

Secretario Técnico

Roberto Guerra M.

Jefe del Departamento de Ediciones 


\title{
LA GRAN MUTACIÓN \\ El capitalismo real del siglo XXI
}

\author{
Óscar Ugarteche \\ Eduardo Martínez-Ávila
}


Esta investigación, arbitrada por pares académicos, se privilegia con el aval de la institución editora.

\section{Ugarteche, Óscar}

La gran mutación : el capitalismo real del siglo XXI / Óscar Ugarteche, Eduardo Martínez-Ávila. -- Primera edición. -- México : UNAM, Instituto de Investigaciones Económicas, 2013. - (Breviarios de Investigaciones Económicas)

124 páginas : gráficas; $18 \mathrm{~cm}$.

Bibliografía: páginas 115-122

ISBN 978-607-02-4504-6

1. Política económica. 2. Globalización - Aspectos económicos. 3. Crisis financiera mundial, 2008-2009. I. Martínez-Ávila, Eduardo. II. Universidad Nacional Autónoma de México. Instituto de Investigaciones Económicas. III. título. III. Serie.

338.9-scdd21 Biblioteca Nacional de México

Primera edición

17 de julio de 2013

D.R. (C) Universidad Nacional Autónoma de MéXICO

Ciudad Universitaria, Coyoacán, 04510, México, D.F.

INSTITUTO DE INVESTIGACIONES ECONÓMICAS

Circuito Mario de la Cueva s/n

Ciudad de la Investigación en Humanidades

04510, México, D.F.

ISBN: 978-607-02-4504-6

Cuidado de la edición: Hélida De Sales Yordi.

Diseño de portada: Victoria Jiménez Sánchez.

Prohibida la reproducción total o parcial por cualquier medio sin la autorización escrita del titular de los derechos patrimoniales.

Impreso y hecho en México 
Para Javier Díez Canseco.

Para Margarita. 
[...] Y es un mundo que no sabemos nombrar. Si uno le dice a Dante, ¿qué se siente estando en plena Edad Media?, él nos diría: "YY qué es la Edad Media?" No podemos nombrar esta época pero sentimos que todo está cambiando.

Carlos Fuentes diario El País, 14 mayo, 2012 


\section{ÍNDICE}

$\begin{array}{ll}\text { PRESENTACIÓN } & 13\end{array}$

Prólogo: a propósito de Foucault y la llustración. Elementos PARA COMPRENDER LA ECONOMÍA Y LA CRISIS

1. UNA PERSPECTIVA HISTÓRICA

2. DEL SISTEMA FINANCIERO AL COMPLEJO FINANCIERO BANCARIO

3. LA CRECIENTE CONCENTRACIÓN DEL INGRESO EN EL MUNDO, 1970-2010

EpÍLOGO 


\section{PRESENTACIÓN}

La colección Breviarios de Investigaciones Económicas ofrece a los lectores temas actuales, de interés social y académico, presentados de manera sucinta y atractiva. Asimismo, están elaborados con un amplio panorama, rigor y acuciosidad en el análisis de los temas a tratar.

Los autores, especialistas en la materia que tratan, decantan el saber vigente; cada Breviario entonces se convierte en una oportunidad para conocer el nivel de la temática abordada y cumple con el propósito de despertar el interés del lector, poniendo a su disposición la bibliografía pertinente para profundizar en el tema tratado.

El otro propósito de los Breviarios de Investigaciones Económicas es hacer que el conocimiento llegue a más personas, una de las actividades fundamentales de la Universidad Nacional Autónoma de México y, por ende, del Instituto de Investigaciones Económicas, porque difundir es reproducir y acrecentar el saber.

Verónica Villarespe Reyes

Directora

Instituto de Investigaciones Económicas, UNAM 


\section{PRÓLOGO \\ A PROPÓSITO DE FOUCAULTY LA ILUSTRACIÓN. \\ ELEMENTOS PARA COMPRENDER \\ LA ECONOMÍA Y LA CRISIS}

Doscientos años después de que surgiera la verdad revelada, en la Edad de la Razón, la humanidad se enfrenta otra vez a una nueva verdad revelada: el mercado. Si Dios era el portador de la verdad, y el conocimiento era un obstáculo fácilmente salvable para garantizar que dicha verdad se mantuviera, hoy día Dios es el mercado. El mercado es omnipresente y perfecto: todo lo sabe y todo lo puede, habla y escucha, en todo el orbe. El conocimiento, en cambio, no impide que dicha verdad continúe extendiéndose como un dogma. Esa es la función de las teorías neoliberales en lo económico y neoconservadoras en lo político, que conforman la posmodernidad en el modo de entender el inicio del siglo xxı. En este campo, la filosofía política va por delante de la experiencia y propone un ordenamiento social inexistente, y que solo se da a partir de las relaciones individuales. No hay intereses de clase, de sexo, étnicos, raciales, religiosos, de género, ni nacionales. Solo individuales que deben ser atendidos de inmediato. La inmediatez es un elemento de esta posmodernidad individualista llevada al extremo: la del agente económico aislado y sus necesidades infinitas.

Foucault [1988] en Sujeto y poder, advierte que el sujeto humano está inmerso en relaciones de producción y de 
significación y, por tanto, en relaciones de poder muy complejas. La interrogante que plantea es ¿qué legitima el poder? ¿Cómo se construye el significante del poder? Una vez con una teoría del poder, se puede llevar a cabo una aproximación al análisis de la realidad. La búsqueda de Foucault no es la de Weber. No busca la parte institucional del poder, sino el cómo opera en las conciencias. Busca el proceso de sujeción; cómo se define la norma y lo que está fuera de la misma. Sin ir muy lejos, cómo invade el sentido común y lo transforma mediante las ideas que quiere utilizar para someter, dentro de un contexto histórico muy definido, económico y político.

El fascismo y el estalinismo fueron dos formas patológicas de poder dentro de contextos muy precisos. El poder puede por tanto transformarse para someter del modo que sea más factible. Toda la discusión se lleva a cabo sobre el espacio del poder y de qué manera invade y somete al sujeto humano. A pesar de su "locura interna", ambas formas usaron las ideas y los procedimientos de nuestra racionalidad política. De la misma manera, hoy día el mercado ha sometido la razón y la política con el soporte político neoconservador, más próximo al fascismo que al estalinismo, pero lejos de los espacios democráticos en construcción a partir del siglo xvIII. Esto es cierto para Estados Unidos y Gran Bretaña, pero también lo es para gran parte de Europa y América Latina. En la nueva visión, la interacción sociedad-Estado es intermediada por el mercado, le pese a quien le pese. Todo lo que se aleja de esta interacción es anatema, se aleja del dogma y debe de ser "excomulgado": por ejemplo Venezuela, Ecuador, Bolivia, la "mala izquierda" en palabras de un 
político neoconservador mexicano antes perteneciente al Partido Comunista.

Dice Foucault que la palabra racionalidad es peligrosa. No hay que invocar el proceso de racionalización en general, dice. Pero del otro lado, en la teoría económica contemporánea dominante, en el dogma, la racionalidad es la esencia. Los sujetos son siempre "racionales" y deciden siempre sobre lo que optimiza su función de utilidad. El problema con esta aproximación teórica es que niega lo razonable y también lo poco razonable: los impulsos. "Lo quiero y me lo llevo" no es racional, es humano. "Yo regalo" tiene que ver con formas de enlace y no con una función de utilidad. El "nosotros" en el colectivo más amplio no tiene cabida en la sociedad actual.

Empero, como se puede apreciar en la progresión del neoliberalismo primero, y en la crisis del milenio después, los autoritarismos y las intolerancias avanzan y se van constituyendo como nuevos sentidos comunes. El torturar en vez de detener; matar en lugar de hacer justicia; deportar en vez de proporcionar mejores condiciones de trabajo. Se puede observar una regresión social sustentada en la división absoluta de la sociedad después del colapso del socialismo real. Sindicatos destrozados en el nombre de la generación de empleo (que no se da); universidades públicas devastadas en el nombre de la libre empresa en la era del conocimiento (sin evidencia de éxito); el sujeto político ha dejado de ser ciudadano y ha sido transformado en consumidor. Con salarios deprimidos y la necesidad de consumo inyectada en el sentido común, el consumidor se convierte en un deudor que debe los ingresos que obtendrá por el resto de su vida por haber logrado vivir algo "más allá de su capacidad". 
Y es ahí donde se muestra la crisis. Inmersa en economías maduras estancadas, con mediocres tasas de crecimiento de la productividad y altísimo consumo; los consumidores, exciudadanos, deben a la banca, al fisco, y al prójimo, y se van quedando sin empleo. Cuando se ha dejado de ser ciudadano, no se tienen derechos más allá que los de ser consumidor. Por esta razón la protesta social es reprimida en todo el mundo usando como argumento el "terrorismo"y por ello los líderes de la protesta pueden acabar en la cárcel sin acusación, como sucedió con Assange, que ha quedado en ausencia de los derechos mínimos, como el asilo diplomático. Para algunos neoconservadores, el derecho de asilo es una perversión legal de los países "atrasados".

Los ciudadanos y ciudadanas habían conquistado derechos que se fueron construyendo desde la Revolución francesa, es decir, desde el inicio de la modernidad. Una de las promesas del proyecto civilizatorio es la igualdad ante la ley, y eso tiene que ver con franquicia política y de ciudadanía. Por ello se han ido incorporando de manera progresiva al voto ciudadano indígenas, "analfabetos", afrodescendientes y mujeres que concilian con la sociabilidad del mundo occidental. En cambio, los consumidores no tienen sino derechos sobre lo que consumen. Los derechos políticos se han ido desvaneciendo, al tiempo que se habla de la "democracia" como valor supremo. La democracia es un bien de consumo que se expresa mediante encuestas de opinión de mercado. La arbitrariedad del trato en el traslado por los aeropuertos es el mejor ejemplo. Un pasaporte sospechoso puede llevar al sujeto a ser revisado por posesión de drogas y a la deportación, sin ninguna razón aparente; 0 sencillamente, quedarse varado esperando alguna decisión 
arbitraria sobre si tiene o no derecho de paso en ese aeropuerto "internacional". La apariencia también puede llevar a la muerte, como en el caso del brasileño Jean Charles de Menezes, asesinado por las fuerzas de seguridad británicas tras el atentado en Londres del año 2005. Su asesinato, incomprensible, se transformó en una razón de Estado."Matar por las dudas". No hubo justicia, no hubo detención, ni reconocimiento de su estatus de ciudadano de algún país en otro territorio, el Reino Unido en este caso. Se trataba de un consumidor de color, fuera de sitio, probablemente desempleado, de un barrio marginado: un terrorista. Era un excluido que no merecía ningún respeto como ciudadano, o como ser humano.

Hemos ido regresando a etapas que se pensaba superadas e imposibles de retorno: de muertes de Estado arbitrarias, colocando a este por encima de la ley. Los musulmanes de hoy en Europa son los judíos de los años treinta del siglo xx. Subordinados, maltratados y discriminados, han llegado a ser los chivos expiatorios de la crisis. Los 150 inmigrantes musulmanes muertos en Alemania, cuyos casos han sido ocultados por la policía, encubriendo su responsabilidad, fue una repetición de nuevo cuño de procesos anteriores de entreguerras. Fenómenos análogos se han visto por ejemplo en Noruega, donde un supremacista mató a decenas de estudiantes porque "serían"tolerantes en el futuro, por nombrar el caso más notorio. Los retrocesos dentro de la política en Estados Unidos; la situación del Vaticano; la política migratoria europea, y la persistencia de una teoría económica lanzada en una trayectoria crítica que no puede detener, hacen pensar que el poder mutó a un pequeño conjunto de actores que tienen que ver con la riqueza de 
un sector y no con el desplazamiento del poder entre un país y otro, entre un hegemón y otro; o entre un conjunto de ideas y otro. El retroceso social, aunado al político, y la persistencia de una crisis de gran magnitud en las economías líderes abren interrogantes sobre los fundamentos filosóficos del poder. ¿La razón?

El papel que desempeña la filosofía es impedir que la razón vaya más allá de los límites dados por la experiencia, dice Foucault a propósito de Kant. Este, por su lado, dice en ¿Qué es la llustración?

[...] La ilustración es la liberación del hombre de su culpable incapacidad. La incapacidad significa la imposibilidad de servirse de su inteligencia sin la guía de otro. Esta incapacidad es culpable porque su causa no reside en la falta de inteligencia sino de decisión y valor para servirse por sí mismo de ella sin la tutela de otro. jSapere aude!

El papel del maestro, dice Kant, es restringir el espacio del pupilo y advertirle sobre los peligros de caminar solo en búsqueda de la verdad y la razón. Es decir, el objeto de la escuela para Kant es limitar el conocimiento y canalizar el dogma. No busca más, aunque si el sujeto es un buen maestro, tendrá un espacio donde repetir el dogma y otro donde discutir sus propias ideas. Eso hace un buen maestro. La mayor parte, sin embargo, enclavan prejuicios y terminan víctimas de estos.

La libertad es esencial para la búsqueda. Foucault, en su ensayo breve titulado igual que el de Kant ¿Qué es la ilustra-

${ }^{1}$ ¡Ten audacia de saber! 
ción? desmenuza las posturas del filósofo alemán y plantea el problema del conocimiento y la libertad de conciencia

[... Cabría pensar que no hay en ello nada muy diferente de lo que se entiende, desde el siglo xvı, por la libertad de conciencia: el derecho a pensar como se quiera con tal que se obedezca como se debe. Ahora bien, es aquí donde Kant hace intervenir otra distinción y de una manera bastante sorprendente. Se trata de la distinción entre uso privado y uso público de la razón; pero a continuación añade que la razón debe ser libre en su uso púbico y sumisa en su uso privado. Lo que es, palabra por palabra, lo contrario de lo que se llama de ordinario la libertad de conciencia.

La dificultad e interrogante para Foucault sería ¿cuánto espacio tiene el docto para distanciarse del dogma antes de ser anatemizado? Lo cierto es que en cuanto docto, el sujeto gravita sobre una postura crítica y el dogma. En esa medida, además, no puede ser frenado. Por otro lado, si el cuestionamiento del dogma es lo suficientemente fuerte, ¿pertenece aún a la congregación de los creyentes?

En estos tiempos en los que el dogma económico corre libremente, se ha llegado a advertir sobre los peligros de enseñar algunos postulados teóricos, estigmatizando lo que no es parte del dogma, cerrándose a las escuelas heterodoxas y castigando la enseñanza del marxismo, por ejemplo. Quizá sea el momento de abrir las puertas a la razón y otras formas de concebir la praxis, como la propuesta del sociólogo colombiano Orlando Fals Borda [2009] que considera que el ser humano es un ser sentipensante, que combina el aspecto vivencial-emocional con el racional, y deja que fluyan otras 
formas de conocimiento en pos de una mejor comprensión de la realidad.

Para abordar esta temática, este pequeño trabajo está dividido en tres partes. El primer capítulo lidia con la naturaleza compleja de la crisis y los aspectos financieros, terminando con los retos pendientes por resolver; es el fruto de una serie de conferencias, una del año 2008, organizada por la Unesco, dentro del proyecto most; otra del año 2009 en el Congreso de la República de Ecuador, y una tercera que se llevó a cabo durante la inauguración del año lectivo 2009, en la Escuela Preparatoria 1 de la unAm, en México. El segundo capítulo aborda la existencia y pervivencia del sistema financiero, y analiza si algo ha cambiado en esencia. También se encuentra basado en una conferencia presentada en las IX Jornadas Monetarias del Banco Central de la República Argentina, en Buenos Aires, en octubre 1 y 2 del 2012. El capítulo 3 estudia la concentración del ingreso como objeto de la financiarización y la política económica en los últimos treinta años.

La propuesta general plantea que la presente, es una crisis múltiple y transdisciplinaria; que el complejo financiero ha tomado el control de la marcha económica y del Estado en Gran Bretaña y Estados Unidos desde los años ochenta dentro del campo económico-financiero, lo cual ha avanzado de manera creciente, por lo que se ha llegado a sostener tanto un sentido común académico, como una política macroeconómica cuya finalidad es concentrar el ingreso. Dada la evidencia contundente que se ha presentado desde África hasta Europa en las últimas décadas, el objeto de la política macroeconómica no ha sido estabilizar la macroeconomía, sino concentrar el ingreso, 
El marco foucaultiano sirve para abrir caminos de comprensión, que a su vez den espacio para proponer nuevas lecturas, tanto de la crisis, como de las razones para comprenderla de manera más amplia. También, su lectura puede ser utilizada para la acción: conocer es poder.

Queremos agradecer a Teresita de Barbieri y Nelson Minello; a Frei Betto y Pablo González Casanova; a los asistentes de la II Conferencia internacional, "Juárez, Bolívar, Martí. Crisis civilizatoria y alternativas antisistémicas", del 19 y 20 de marzo 2012 en la Facultad de Economía de la unAm; y a los asistentes al Seminario de Economía Mundial, del Instituto de Investigaciones Económicas. Asimismo, debemos hacer énfasis en la generosidad del doctor Nelson Minello, de El Colegio de México, por acudir al IIEC UNAM y asesorarnos en la búsqueda del conocimiento, y a los asistentes de nuestro pequeño grupo, en particular a Jorge Málaga, por las estupendas discusiones que han servido para abrir conciencias. Las lecturas posteriores de Carlos Welti, del Instituto de Investigaciones Sociales, y de Fidel Aroche, de la Facultad de Economía, ambos de la unam, nos convencieron que era momento de dar a luz este trabajo. A nuestros asistentes, Francisco Martínez Cervantes, Ariel Noyola Rodríguez y Luis David Ramírez Benítez les quedamos muy agradecidos. Como siempre, también al equipo editorial del IEC, en particular a Roberto Guerra Milligan.

Ciudad Universitaria, Coyoacán, 07 de marzo de 2013 


\section{UNA PERSPECTIVA HISTÓRICA}

INTRODUCCIÓN

Estamos ante una crisis de naturaleza compleja, que abarca dimensiones que distan de ser similares a las grandes crisis económicas de 1929, 1872 y 1825 [Marichal, 2010]. Parece ser una crisis de cambio de época, como la que hubo entre fines del siglo XVII y mediados del XVIII, que entreteje aspectos económicos, ambientales, financieros, energéticos, de género, demográficos, de creencias, teóricos y tecnológicos. Si entonces el fruto fue la modernidad, ahora los referentes civilizatorios se encuentran bajo discusión. [Frei Betto [2012] refiere esto como una crisis que está en un cambio de época hacia la "posmodernidad", es decir, hacia una etapa entendida como después de lo moderno. La modernidad trajo consigo la noción de progreso, basado en la transformación de la naturaleza por el ser humano. Hoy, el ser humano ha logrado construir un mundo que en pocas décadas será invivible.

En esa medida, se estaría ante los límites de los paradigmas de la modernidad, el capitalismo y el socialismo, basados en la noción de progreso como la transformación de la naturaleza por el ser humano. El patrón actual energético de combustibles fósiles no es compatible con la prolongación 
de la esperanza de vida. ${ }^{2}$ En un contexto de ampliación de clases medias, el crecimiento demográfico con respecto a la reproducción del patrón energético anclado en la combustión fósil ${ }^{3}$ y el modelo de consumo energético estadounidense han derivado en problemas ecológicos relacionados con el calentamiento global, y en la sobreexplotación de la tierra y sus recursos. La única certeza es que los límites ambientales están planteados y, de mantenerse el mismo patrón de acumulación y forma de producción, la vida en el planeta será difícil a un siglo de distancia [Aguayo, 2012].

Nos encontramos ante una crisis de sobreproducción, apreciada desde la teoría económica como una crisis de largo aliento en el ciclo de Kondratieff [Schuldt, 2011; Sandoval, 2004]. Esto la convertiría en una crisis de cambio tecnológico en la que, según los postulados de Schumpeter, debe haber destrucción creadora para salir. O mejor, como propone Pérez [2004] se trata de una crisis que abrirá el espacio para la masificación de tecnologías ya existentes, pero aún no generalizadas, siempre que los Estados tomen las políticas correctas y regresen al sector productivo su

2 Disponible en: http://eleconomista.com.mx/mercados-estadisticas/2012/08/17/demanda-crudo-cae-su-menor-nivel-casi-cuatroanos-api [Consulta: 30 de agosto de 2012].

${ }^{3}$ La emisión creciente de dióxido de carbono per cápita a nivel global ha crecido 1.14\% anualizado a partir de 1960. Según el Banco Mundial, en 2008 la emisión promedio per cápita en el mundo fue de 4.8 toneladas de dióxido de carbono; sin embargo, las naciones de capitalismo avanzado, particularmente las naciones integrantes de la Organización para la Cooperación y Desarrollo Económico [OCDE], emitieron 10.51 toneladas por habitante. Banco Mundial. Disponible en http://datos.bancomundial.org/indicador/EN.ATM.CO2E.PC/countries/1W-US?display=map [Consulta: 30 de agosto de 2012]. 
sentido generador de valor. La nueva economía mundial privilegia el capital financiero trasnacional, en detrimento del capital productivo y de participación activa del Estado, fomentando la concentración del ingreso en el complejo financiero bancario y en los sectores extractivos y energéticos [Robinson, 2011]. La financiarización generada por la falta de rentabilidad del sector real desde los años setenta [Duménil y Levy, 2002; Morera y Rojas, 2011] ha llevado a una economía ficticia, diez veces mayor que el PIB mundial real, ${ }^{4}$ que es controlada esencialmente desde el complejo financiero bancario estadounidense y británico. Este ha creado una ficción teórica que da precio a instrumentos financieros derivados de un valor real subyacente a partir de un mecanismo de concentración del ingreso mundial. Por ejemplo, el valor financiero de una vaca. Un bovino realmente existente se transforma en un activo financiero con un precio, determinado en el mercado internacional de ganado. ${ }^{5}$ Ese activo financiero se puede a) vender, b) vender hoy y recomprar en diferido, c) vender a futuro, d) alquilar o e) prendar. De la misma manera, se pueden vender los flujos de ingresos por la venta de " $x$ "litros de leche producidos en " $y$ " años. Asimismo, se pueden vender los derechos de compra de los " $n$ " terneros que parirá la vaca en su vida útil, que si bien no han nacido es probable que lo hagan durante la vida del animal. Como hay una alta probabilidad que las terneras produzcan leche, se pueden vender

${ }^{4}$ BIS. Disponible en http://www.bis.org/statistics/otcder/dt1920a.pdf [Consulta: 30 de noviembre de 2012].

${ }^{5}$ Disponible en http://www.trademeats.com/ [Consulta: 30 de noviembre de 2012]. 
los derechos de compra de la leche de cada animal a terceros. La leche sirve para hacer queso y mantequilla, con lo que se puede vender el derecho de compra del queso y la mantequilla de las ocho terneras que probablemente se produzca. Así, a partir de una vaca realmente existente, se crea en este ejemplo una economía ficticia construida por probabilidades mediante 25 activos financieros que tienen un mercado y un precio. De esta manera se ha llegado a construir una economía financiera diez veces mayor que el PIB mundial.

Los instrumentos financieros han dejado de ser el medio entre el ahorro y la inversión-producción y consumo, como se plantea en la visión monetarista y en la comprensión neoliberal, fungiendo como objetos de "inversión"en sí mismos. Los bancos dejaron de prestar y comenzaron a "invertir" desde los años ochenta, a partir de la generalización de la teoría de los mercados financieros eficientes expresada por los profesores de la Universidad de Chicago, Fama, Miller y Modigliani. Empero, como la riqueza mundial sale de la producción real, eso exige una concentración del ingreso mundial y de los ingresos nacionales muy acentuada y requiere de la liberalización de los mercados financieros en el mundo.

En este contexto, Europa, Estados Unidos y Japón se enfrentan a una crisis financiera de sobreproducción, fiscal y al deterioro de su calificación crediticia debido a que las calificadoras de riesgo ${ }^{6}$ les han degradado de su nivel histórico AAA. En contraste, las economías emergentes de un nuevo G7 -China, Brasil, Indonesia, Corea del Sur, Rusia, In-

${ }^{6}$ Fitch's, Moody's, Standard and Poor's. 
dia, y Turquía - representan 50\% del Producto Interno Bruto (PIB) del viejo G-7 y crecen de manera acelerada. La dinámica saludable de las economías latinoamericanas, africanas y asiáticas se explica en esencia por la especulación de las materias primas en el mercado de derivados [Unctad, 2011]. La determinación de los precios viene dada por las tasas de interés, que siendo bajas o negativas en la primera década del siglo XxI impactan a la inversa sobre estos.

La novedad entonces, es que la especulación de las materias primas está siendo alimentada por la financiarización, la desregulación financiera, las tasas de interés reales cercanas a cero o negativas de la primera década del siglo. La especulación se alimenta de los variados rumores de guerra con un impacto positivo, aunque efímero, sobre los exportadores de materias primas. A esto se suma la demanda creciente de commodities por las economías asiáticas, lo que las hace más estables. El resultado final es que las economías exportadoras de materias primas crecen fuertemente, mientras las economías maduras no lo hacen.

Por otra parte, la guerra, que hasta la década de los años setenta era un motor para sacar del estancamiento a las economías, por sus eslabonamientos internos multiplicadores, ha pasado a ser un negocio. La duplicación del presupuesto militar en el PIB de Estados Unidos entre el año 2001 y 2010 no ha generado crecimiento. En cambio, ha dado lugar a pingües ganancias a las empresas directamente involucradas. En la dinámica de mercantilizar la vida humana, los bienes públicos globales se hallan en extinción. La seguridad se ha transformado en un negocio mediante la privatización de los ejércitos, lo que convierte a la guerra en una empresa que no arriesga ninguna ban- 
dera nacional. Esto fue claro en Libia y Siria pero también lo es en Irak y Afganistán. El proceso de privatización de la seguridad se utiliza también para el control social mediante la penalización de la protesta en general y para vigilar el movimiento internacional de personas. La masificación del proceso de vigilancia es parte del proyecto militar estadounidense.? En realidad, "el nuevo siglo americano" no busca el reposicionamiento de su hegemonía al estilo Gramsci, sino hacer negocios. Con el mismo razonamiento, el aire como un bien público global se ha financiarizado y puede ser convertido en bonos de carbono que dan lugar a un mercado. Esto no descontamina pero genera ingresos a personas o empresas con actividades forestales y a los bancos. La privatización del agua mediante el embotellamiento, acompañada de campañas sobre la mala calidad del agua de grifo, y la privatización de los servicios públicos de salud y educación, todo sumado terminan mercantilizando la vida, como sugiere Frei Betto [2012].

Socialmente, los problemas de migración derivados de la ampliación de la esperanza de vida en un contexto en el que se desplaza la fuerza de trabajo, individual viva por trabajo socialmente acumulado [Quijano, 2010] y de la polarización de los ingresos globales está generando xenofobia y expresiones de odio racial solo vistos en los años treinta. El maltrato europeo a los no europeos; o el estadounidense a los mexicanos y latinoamericanos, se expresan en deportaciones masivas.

7 Disponible en: http://www.csmonitor.com/USA/2012/0616/Dronesover-America.-Are-they-spying-on-you [Consulta: 30 de julio de 2012]. 
Con respecto a la crisis de género, las desigualdades se basan por lo general, en la ideología hegemónica que vincula el rol de las mujeres a las actividades de la esfera privada, relacionadas con la feminidad y la maternidad. Aun cuando se observa una inserción masiva de las mujeres en el mercado de trabajo, principalmente en zonas urbanas, se han desarrollado procesos sistémicos que tienden a abaratar los salarios en general, observándose una mayor disminución en las actividades realizadas por las mujeres. ${ }^{8}$ Lo anterior puede explicarse en función de que las remuneraciones hacia las mujeres siguen siendo consideradas complementarias con respecto al salario de los hombres. Hoy día, la literatura académica ha discutido la categoría "economía del cuidado" relacionada con aquellos actos que satisfacen las necesidades materiales y emocionales de los seres humanos como condición indispensable para la reproducción del modelo económico, actos principalmente encabezados por mujeres que satisfacen las necesidades de su familia sin remuneración y reconocimiento alguno [Ravazi, 2007; Esquivel, 2011].

Por otro lado, los cambios tecnológicos se diseñan en las economías maduras para reducir el costo de la mano de obra, pero en las economías emergentes dicha tecnología reduce el empleo nuevo, lo que resulta en migración. Por último, el proceso de tercerización (outsourcing) ha dado lugar a cadenas globales de valor, lo que conlleva una huella

${ }^{8}$ En 2009 las cifras de la feminización de la pobreza en América Latina mostraron tasas de paro laboral entre 6 y $16 \%$. En contraste, se observa que el índice de desempleo en los hombres estuvo entre 5.7 y $12.1 \%$ [Montaño y Milosavljevic, 2010]. 
ecológica creciente por el proceso de traslado de los bienes tanto en la fase de fabricación como de ventas globales.

Como se puede apreciar, nos encontramos ante una crisis de carácter civilizatorio [Quijano 2010; Santos 2010] o mejor aún, "ante un cambio de tiempos" que arrastra grandes costos sociales. En función de lo anterior, el objetivo de este ensayo es analizar, desde una postura histórica y económica, los diversos procesos que han desembocado en la actual crisis multidimensional global que todavía afecta en mayor medida a las economías de capitalismo avanzado.

El presente capítulo se divide en dos grandes partes; la primera examina el desenvolvimiento de la crisis a partir del año 2007 y hace una disección de los distintos momentos de su evolución. La segunda aborda la reconfiguración del sistema capitalista de producción. Para ello se revisa el proceso de transición que modificó el patrón tecnológico en la década de los años setenta en función de la caída de la tasa de ganancia industrial en las economías desarrolladas. Por último, se revisa la financiarización de la economía y la importancia del complejo militar-industrial dentro del contexto de los límites ambientales para el crecimiento.

LA CRIIIS HEGEMÓNICA Y SU DESENVOLVIMIENTO: 2007-2012

Schuldt [2011] ha propuesto una explicación conceptual de la crisis desde los ciclos de larga duración de Kondratieff, también trabajados por Sandoval [2004]. Se decía que cuando Estados Unidos estornudaba, al mundo le daba pulmonía. La verdad es que la enfermedad de Estados Uni- 
dos del 2007 impactó en las naciones maduras, que se encuentran articuladas entre sí, y le contagió el virus en pleno, primero al sistema financiero internacional, y luego a la economía productiva de las economías europeas, tras sus ajustes al consumo y al gasto público. La decisión de aplicar políticas crediticias expansivas en Estados Unidos, Europa y luego Japón, ha empujado -como ya se ha mencionadolos precios de las materias primas al alza, lo que ha llevado al crecimiento en los países exportadores primarios, que a su vez tienen bajos niveles de deuda externa. Eso explica las dos velocidades de la crisis. Cuando se recupere la economía de Estados Unidos y la tasa de interés suba, se contagiarán de pulmonía las economías emergentes.

De la misma manera que ocurrió en 1929, lo que empezó como un problema de finanzas, muestra una complicación mayor que abarca la esfera real de la economía, en la que no se puede salir de la crisis mediante la teoría que la generó. Aunque este sea un aspecto académico, no hay que dejar de señalar que los ajustes económicos que Alemania vía la troika (FMI-Unión Europea-BCE) impone a los gobiernos europeos son análogos a los que Estados Unidos vía el FMI implantó en los gobiernos de América Latina en su tiempo, conforme los postulados de la teoría hayekiana. Ante esto, es necesario cuestionar y resignificar, desde las distintas ópticas, las categorías que utilizamos para no correr el riesgo de reflexionar sobre una realidad ficticia, debido a que el ritmo de la realidad no es paralelo al ritmo de las construcciones conceptuales [Zemelman, 2004]. 
Momentos DE LA CRIIS: AGOSTO 2007-MARZO 2012

Se pueden reconocer ocho momentos de la crisis, entre agosto del 2007 y marzo de 2012, si se toma como punto de partida el problema de las hipotecas de mala calidad. Luego, la crisis se abre como una cebolla, en distintas capas, y cada una se va desplegando en la siguiente. Metafóricamente, cuando se haya terminado de abrir la cebolla, saldrá a flor la nueva era económica [Ugarteche, 2012a]:

1. La crisis de las hipotecas de mala calidad (Subprime) (agosto 2007- septiembre 2008): ante un panorama monetario estadounidense con tasas de interés cercanas a cero entre 2002 y 2003, pero que en el año 2004 comenzaron a subir de nuevo, llevó a que los inversionistas en el sector de bienes raíces lo abandonaran; no obstante, en Estados Unidos prevaleció un entorno de exceso de liquidez.

Los efectos de las bajas tasas de interés fueron el inicio del auge en el precio de las materias primas, con el impacto positivo sobre el crecimiento de sus economías exportadoras y, por otro lado, un auge en el mercado de bienes raíces de Estados Unidos sobre todo, pero generalizado en todo el mundo. En Estados Unidos, la banca comercial y de inversión, que acumulaba dinero sin mayor posibilidad de recirculación, lo prestó de manera irrestricta en el mercado de bienes raíces, circunstancia que infló una burbuja especulativa. Ante el incremento del valor de los activos, los banqueros otorgaron más préstamos hipotecarios a personas sin capacidad crediticia. Dado que las hipotecas son activos financieros vendibles, estos activos fueron luego evaluados como instrumentos de buena calidad por las tres más 
reputadas empresas calificadoras de riesgos estadounidenses y vendidos a bancos de inversión. De este modo, los bancos que emitieron las hipotecas riesgosas se deshicieron de ellas y se las vendieron a un banco de inversión. En el camino, ganaron dos comisiones: una por el contrato hipotecario y otra por la venta del instrumento, mientras que eliminaron el riesgo de que no fueran pagadas. Al final, los bancos que compraron las hipotecas se las vendieron al FED en los programas de Quick Easing I, II y III que han Ilegado a sumar dos billones de dólares entre 2010 y 2013.

En el sector real de la economía, las empresas de bienes raíces seguían adquiriendo préstamos para continuar construyendo, aunque en cierto momento no habían más compradores, lo que en el 2004 llevó a una crisis de sobreconstrucción, seguida de una desaceleración en el ritmo de la inversión en el sector (véase gráfica 1). Se pudieron apreciar caídas en los precios de las viviendas del orden de 10\%, entre los meses de agosto del 2007 y del 2008, cuando el índice de precios de Standard \& Poor's [2000 $=100]$ se redujo de 136.4 a 124.3 y luego con la crisis se desplomó, llegando a 82.5 en marzo del $2012^{9}$ (véase gráfica 2). En agosto del 2007 se reconoció que había problemas con los precios de las viviendas y el valor de los préstamos hipotecarios, lo que desembocó en el problema de la banca de inversión, gran negociante en estos instrumentos (Bear Stearns quebró en marzo del 2008 y Lehman Brothers en septiembre del mismo año).

${ }^{9}$ Los interesados pueden ver el S\&P/Case-Shiller Home Price Indices en el portal de http://www.standardandpoors.com/indices/sp-case-shillerhome-price-indices/en/us/?indexld=spusa-cashpidff--p-us---- 
Gráfica 1. Crecimiento del PIB de Estados Unidos trimestral total y residencial del $1^{\text {er }}$ trimestre del 2000 a $4^{\circ}$ trimestre de 2008.

\section{Tasas anuales estacionalizadas}

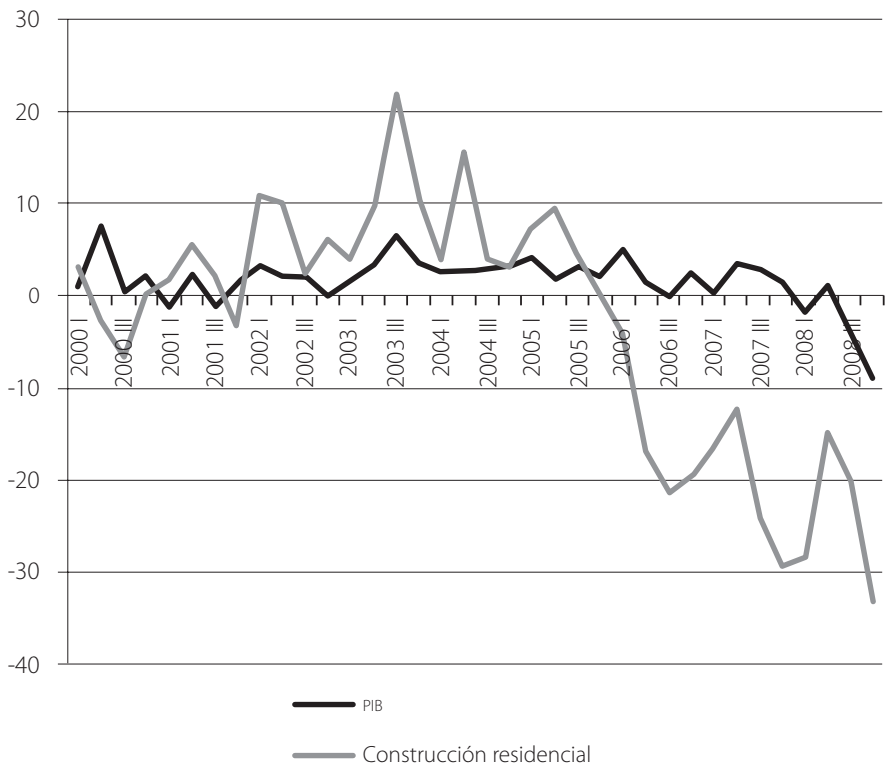

BEA.Disponibleen:http://www.bea.gov/iTable/iTable.cfm?ReqID=13\&step=1 [Consulta: 30 de noviembre de 2012]. Elaboración propia.

En la primera crisis bancaria del siglo xxI el común denominador fue la sobreexposición crediticia, con carteras de mala calidad y corrupción. Entre lo más destacado hay que mencionar los problemas con las hipotecas de mala calidad y los casos de las pirámides financieras de Stanford y Madoff. Se pudo apreciar el rol de las calificadoras de riesgo, que eran pagadas por los bancos clientes que querían vender sus hipotecas; la creación de instrumentos"innovativos" que llevó a la quiebra a la banca de inversión como se 
Gráfica 2. Precios de las viviendas (en dólares) en Estados Unidos 1970-2012

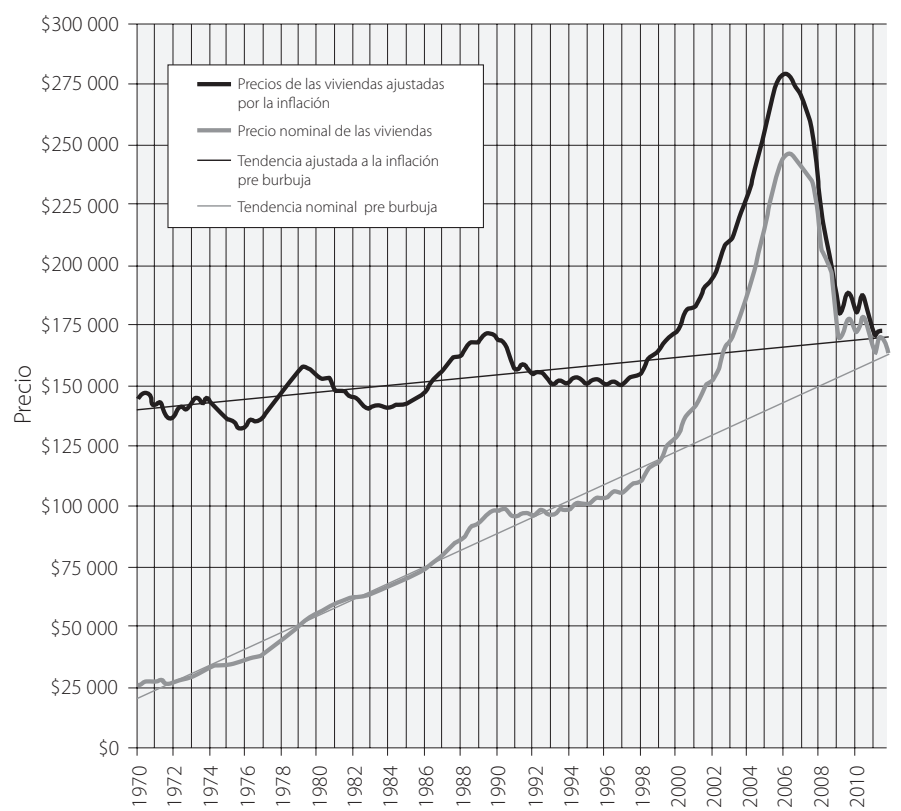

Disponible en: http://www.jparsons.net/housingbubble/ [Consulta: 30 de noviembre de 2012].

le conocía desde el siglo xvilI. Mientras tanto, el expresidente de un banco de inversión pasó a ser secretario del Tesoro ${ }^{10}$ y obligó a que dicha banca se transformara en Bank Holding Companies (BHC) como requisito para beneficiarse de los programas de rescate bancario. El efecto fue que el

${ }^{10}$ Henry Paulson pasó de ser presidente de Goldman Sachs, a secretario del Tesoro en la administración Bush, teniendo 3.23 millones de acciones de Goldman Sachs valoradas entonces en 492 millones de dólares. 
PIB financiero no cayó en el 2009, mientras el PIB nacional de Estados Unidos, y del mundo, sí.

2. El credit crunch (septiembre 2008-junio 2009): el cierre del crédito interbancario en dólares se llevó a cabo en el momento que los bancos comerciales y de inversión se percataron, tras el colapso de Lehman Brothers en septiembre del 2008, que los préstamos interbancarios no eran seguros. La velocidad con la que dicha quiebra impactó sobre la banca europea llevó a intervenciones impensadas. La gran banca europea fue contagiada por el mercado de derivados asociados a las operaciones colateralizadas americanas, lo que puso de relieve la falta de información del mercado y la falta de supervisión global. McGuire y Von Götz, del Banco de Pagos Internacionales (BIS, por sus siglas en inglés), dicen:

La crisis financiera actual ha puesto de manifiesto lo poco que se sabe acerca de la estructura de los balances de los bancos internacionales y de su interconexión. Durante la crisis, muchos bancos de Estados Unidos informan que enfrentan graves carencias de financiamiento en dólares, provocando que los bancos centrales de todo el mundo adopten medidas sin precedentes de política para proveer los fondos. ¿Cómo puede desarrollarse una escasez de dólares tan rápida posterior a una liquidez que había sido tan abundante? ¿Qué sistemas bancarios fueron los más afectados? y, ¿cómo ha afectado las presiones de financiamiento a los fondos de usuarios no bancarios? ${ }^{11}$ [2009: 47].

La respuesta a la contracción de préstamos interbancarios fueron los estímulos mediante la FED, y los programas Quantitative Easing I, II y III, de inyección masiva de dólares sin

${ }^{11}$ Traducción propia. 
Gráfica 3. PIB total y PIB de finanzas, seguros, bienes raíces, alquileres, y arrendamientos financieros 2004-2011 (porcentaje de crecimiento)

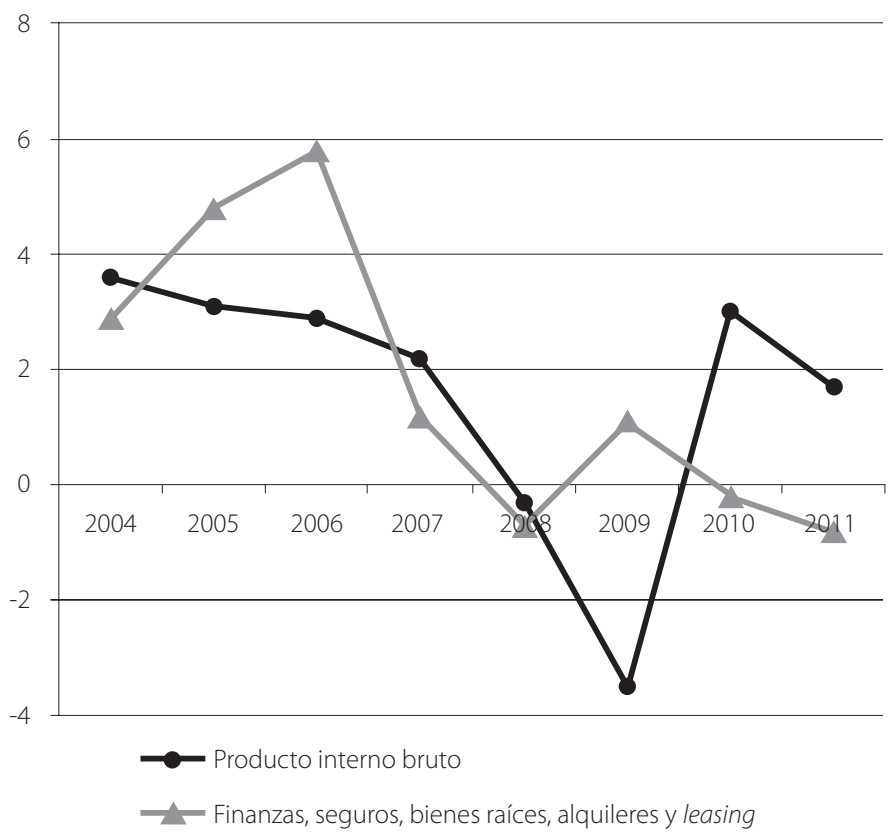

BEA. 2004-2007: Disponible en http://www.bea.gov/scb/pdf/2008/05\%20 May/0508_indy_acct.pdf. 2008-2011: Disponible en http://www.bea.gov/ scb/pdf/2012/05\%20May/0512_industry.pdf [Consulta: 01 de diciembre de 2012]. Elaboración propia.

contraparte real y con ventanillas de descuento a tasas de interés (0.25\%) por debajo de la inflación de los años 2008 y 2009, encima del 2010 y debajo del 2011 en adelante.

Para dimensionar la inyección de liquidez que promovió la FED, la gráfica 4 analiza el nivel de préstamos que ha emitido la Reserva Estadounidense a partir de 1990 hasta junio de 2012, etapa de la inyección paulatina de dólares conforme 


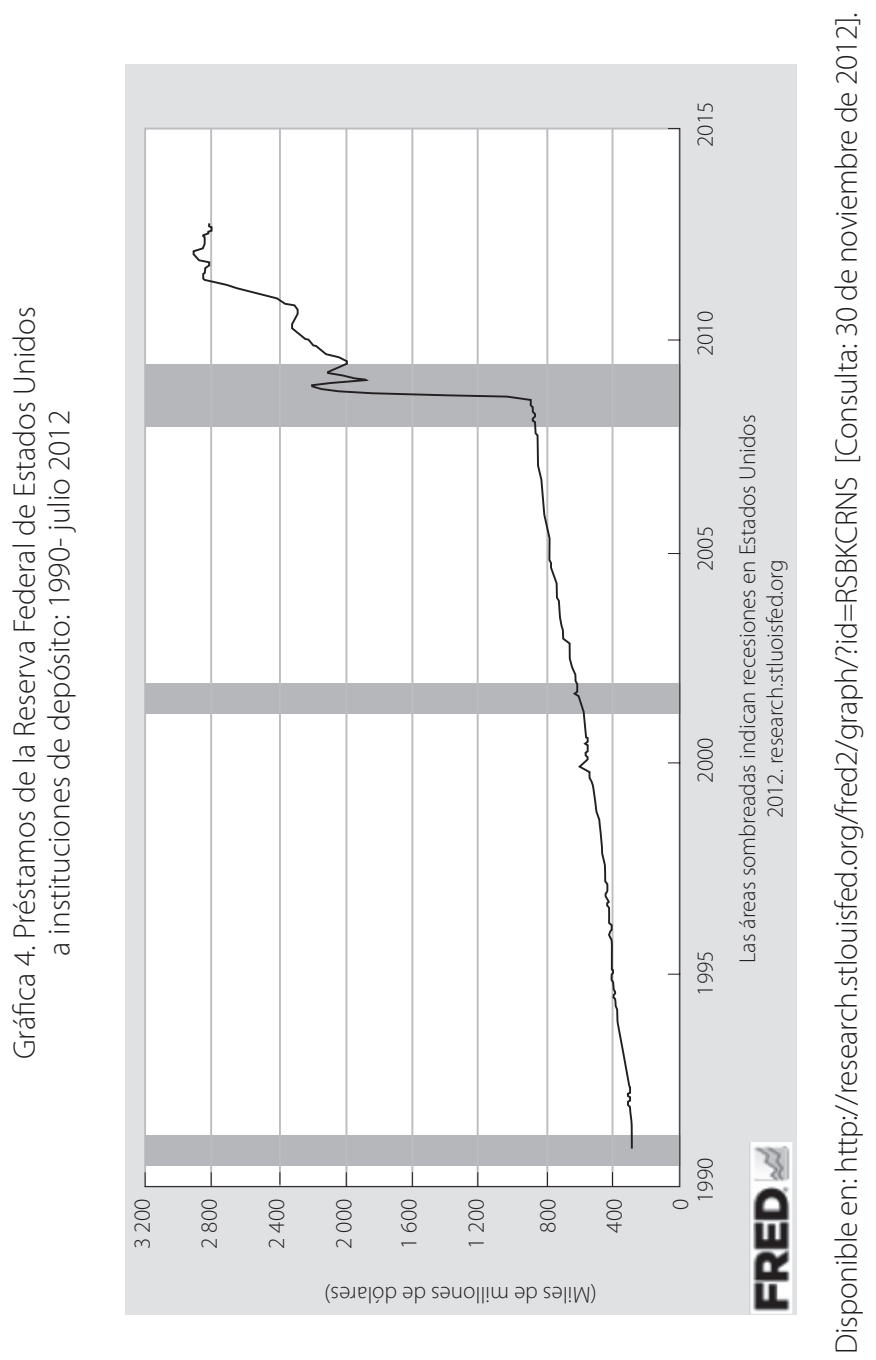


el QE I. Medido en millones de dólares de 2007, el impacto monetario inicial fue de 1.25 billones de dólares entre septiembre del 2008 y el primer trimestre del 2010, en forma de compra de hipotecas sin valor. oE II se llevó a cabo de noviembre de 2010 a junio del 2011; el QE III se inició en septiembre de 2012. Estas inyecciones, a la vez que rescatan a la gran banca, sirven para evitar tendencias deflacionarias por falta de demanda, normales en periodos depresivos como el que se inició en el 2007 (véase gráfica 4).

3. La recesión económica (2009): el desplome del comercio y la recesión mundial resultante en el 2009 afectó en mayor medida a las economías maduras que a las emergentes, que aún se beneficiaron de las tasas de interés cero o negativas estadounidenses y europeas por el auge de commodities en ese mercado. Si se toma el inicio del año 2000 como la base para considerar los flujos comerciales en la década posterior, el índice mundial mostró una caída significativa en 2009, recuperándose en el 2010 los niveles comerciales de 2008.

Las exportaciones entre las 27 naciones adscritas a la región europea disminuyeron entre 2008-2009 en 22.5\%, recuperándose solo parcialmente en 2010 del total comerciado en 2008. Un efecto similar vivieron países emergentes como Brasil, Argentina y México, que aun cuando experimentaron índices hacia la baja en 2009 al igual que las economías maduras, observaron una recuperación comercial, rebasando México y Argentina su nivel de 2008. Por otro lado, el comercio chino fue 10\% superior en el 2010 con respecto al 2008, es decir recuperó la pérdida y la sobrepasó.

Esta diferencia en la velocidad de recuperación comercial generó la idea de una crisis de dos velocidades. Las 
Cuadro 1. Tendencias diferenciadas de las exportaciones en la crisis:

$$
2000=100
$$

\begin{tabular}{lcccc}
\hline \multicolumn{1}{c}{ País } & 2000 & 2008 & 2009 & 2010 \\
\hline Mundo & 100 & 222 & 178 & 212 \\
Unión Europea & 100 & 227 & 176 & 190 \\
México & 100 & 153 & 124 & 160 \\
Brasil & 100 & 273 & 184 & 225 \\
Argentina & 100 & 253 & 208 & 255 \\
China & 100 & 606 & 512 & 672 \\
\hline
\end{tabular}

OMc. Disponible en: http://www.wto.org/spanish/res_s/statis_s/its2011_s/ its11_merch_trade_product_s.htm [Consultado: 30 de noviembre de 2012]. Elaborado por Francisco Josué Martínez Cervantes, proyecto obELA, IIEC-UNAM.

economías emergentes y en desarrollo describieron una tendencia de crecimiento por encima de la media, alrededor de 8\%, en contraste con las economías maduras, cuyo promedio de crecimiento para la década alcanzó en los mejores escenarios 2\% anual en las proyecciones del FMl (véase gráfica 5).

El problema que surgió en 2012 es que la crisis de dos velocidades se abrió a tres; que Europa crecerá entre 0 y $1 \%$ promedio, ${ }^{12}$ incluyendo a Gran Bretaña y Alemania. Estados Unidos crecerá de $1.9 \%$ a $2.4 \%{ }^{13}$ junto con Japón, mientras África, América Latina y Asia parecen estar creciendo

12 BCE. Disponible en: http://www.ecb.int/stats/prices/indic/forecast/ html/table_hist_rgdp.en.html [Consulta: 13 agosto 2012].

${ }^{13}$ fde. Disponible en: http://online.wsj.com/article/BT-CO-20120620-710990. html [Consulta: 13 agosto 2012]. 
Gráfica 5. Crecimiento global del PIB: 2007-2013

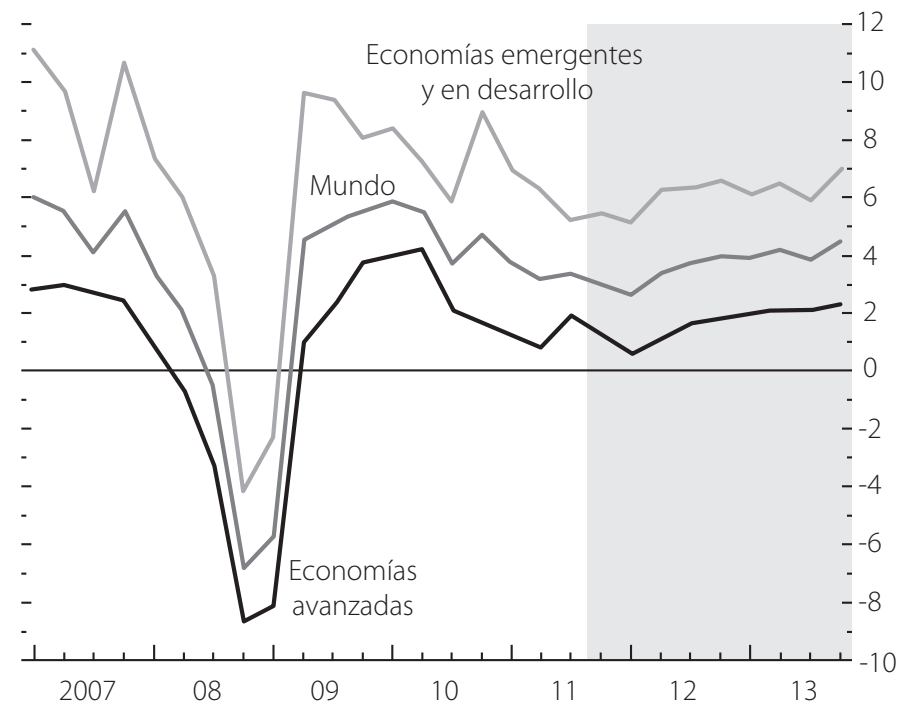

FMI. Disponible en http://www.imf.org/external/pubs/ft/weo/2012/ update/01/pdf/0112.pdf [Consultado: 1 de diciembre de 2012].

mucho más rápidamente. ${ }^{14}$ El efecto de la recuperación de Estados Unidos sobre los flujos de capital de corto plazo puede cambiar estas proyecciones drásticamente.

4. Crisis fiscal en Europa, Gran Bretaña y Estados Unidos (2010): el gran déficit fiscal de las naciones europeas, de Gran Bretaña y Estados Unidos, ha sido originado básicamente por los rescates bancarios, y por la aplicación de políticas contracíclicas. En un segundo momento, son fruto de lo anterior,

14 Bank of Japan. Disponible en: http://www.bloomberg.com/news/201201-24/bank-of-japan-cuts-economic-growth-forecasts-keeps-key-ratesunchanged.html [Consulta: 13 agosto 2012]. 
más el impacto sobre el PIB de inicio de los ajustes fiscales, con su efecto en negativo en la recaudación. Grecia es el caso emblemático (mayo 2010), sin embargo, todas las economías integrantes del G-7 están en la misma situación, por lo que forman parte de los Países Ricos Altamente Endeudados [PRAE].

Los déficits gubernamentales de las naciones desarrolladas mostraron un considerable aumento a partir de 2007. Francia, Italia y Estados Unidos triplicaron su déficit, mientras España y el Reino Unido lo vieron más que cuadriplicarse, y Grecia lo vio crecer en un tercio (véase cuadro 2). El impacto sobre la deuda pública y el peso del servicio de la deuda en los presupuestos nacionales ha sido severo.

Para contemplar el verdadero impacto del monto total de la deuda, es necesario observar los porcentajes de cada nación con respecto al PIB. Lo anterior nos muestra a Francia y Estados Unidos con un monto total de deuda en 2011 por

Cuadro 2. Déficit fiscal como porcentaje del PIB

\begin{tabular}{|c|c|c|c|c|c|c|}
\hline País & 2006 & 2007 & 2008 & 2009 & 2010 & 2011 \\
\hline Alemania & -1.7 & 0.2 & -0.1 & -3.2 & -4.3 & -1.2 \\
\hline Francia & -2.4 & -2.7 & -3.3 & -7.6 & -7.1 & -5.7 \\
\hline Italia & -3.4 & -1.6 & -2.7 & -5.4 & -4.5 & -3.6 \\
\hline España & 2.4 & 1.9 & -4.5 & -11.2 & -9.3 & -6.2 \\
\hline Reino Unido & -2.7 & -2.8 & -5.0 & -11.0 & -10.4 & -9.4 \\
\hline $\begin{array}{l}\text { Estados } \\
\text { Unidos }\end{array}$ & -2.2 & -2.9 & -6.6 & -11.6 & -10.7 & -10.0 \\
\hline Grecia & -6.0 & -6.8 & -9.9 & -15.8 & -10.8 & -9.0 \\
\hline
\end{tabular}


debajo de 100\%; y los casos más preocupantes, la deuda italiana (127.7\%) y helénica (165.1\%) cuyos principales acreedores son la banca francesa y alemana, además de instituciones multilaterales como el fmI y el BCE (véase cuadro 3).

5. Crisis de la deuda soberana de los países del G7 (2011): de una forma sin precedentes, las mayores economías del mundo fueron descalificadas y desacreditadas por las tres calificadores de riesgo de prestigio mundial. Eso comenzó con Grecia y España en el 2010, pero se acentuó de nuevo en el 2011, con Grecia, España, Italia y Portugal; en el primer trimestre de 2012 la agencia de calificación internacional Standard and Poor's degradó a AA los productos financieros de Francia, y Estados Unidos. En marzo de 2012, la Eurozona fue afectada por la descalificación de Grecia, que fue definida en quiebra parcial debido alto riesgo de incumplimiento de pagos. Italia fue evaluada con la califi-

Cuadro 3. Pasivos financieros gubernamentales como porcentaje del PIB

\begin{tabular}{lrrrrrr}
\hline \multicolumn{1}{c}{ País } & 2006 & 2007 & 2008 & 2009 & 2010 & 2011 \\
\hline Alemania & 69.8 & 65.6 & 69.7 & 77.4 & 87.1 & 86.9 \\
Francia & 71.2 & 73 & 79.3 & 90.8 & 95.2 & 98.6 \\
Italia & 116.9 & 112.1 & 114.7 & 127.1 & 126.1 & 127.7 \\
España & 46.2 & 42.3 & 47.7 & 62.9 & 67.1 & 74.1 \\
Reino Unido & 46.0 & 47.2 & 57.4 & 72.4 & 82.2 & 90.0 \\
Estados & 60.9 & 62.1 & 71.4 & 85.0 & 94.2 & 97.6 \\
Unidos & & & & 133.5 & 149.1 & 165.1 \\
Grecia & 116.9 & 115.0 & 118.1 & 13.1 \\
\hline
\end{tabular}

OCDE. Disponible en http://www.oecd-ilibrary.org/content/table/govdfct-table-en [Consulta: 30 de noviembre de 2012]. Elaborado por Francisco Josué Martínez Cervantes, proyecto OBELA, IIEC-UNAM. 
Cuadro 4. Calificación riesgo-país, Standard and Poor's

\begin{tabular}{lccc}
\hline \multicolumn{1}{c}{ País } & Calificación & Panorama & Fecha de emisión \\
\hline Alemania & AAA & estable & 20 febrero 2012 \\
Francia & $\mathrm{AA}+$ & negativo & 20 febrero 2012 \\
Italia & $\mathrm{BBB}+$ & negativo & 13 enero 2012 \\
España & $\mathrm{BBB}-$ & negativo & 13 enero 2012 \\
Japón & $\mathrm{AA}-$ & negativo & $\ldots$ \\
Reino Unido & $\mathrm{AAA}$ & estable & 29 noviembre 2011 \\
Estados Unidos & $\mathrm{AA}+$ & negativo & 29 noviembre 2011 \\
Grecia & $\mathrm{CCC}$ & - & 13 marzo 2012 \\
\hline
\end{tabular}

Disponible en http://www.standardandpoors.com/ratings/sovereigns/ ratings-list/es/la/?sectorName $=$ Governments\&subSectorCode=39\&sta $r t=50 \&$ range $=50$ [Consulta: 30 de noviembre de 2012]. Elaborado por Francisco Josué Martínez Cervantes, proyecto OBELA, IIEC UNAM.

cación BBB+ que está relacionada con la emisión de bonos de mala calidad (véase cuadro 4).

6. La segunda recesión europea (segundo semestre 20112012): esta fase se caracteriza por la aplicación de ajustes fiscales, con la subsecuente caída del consumo y con él, de los ingresos tributarios, lo que juzgado desde una lógica económica ortodoxa ha forzado a más ajustes fiscales, generando una nueva recesión. Los ataques especulativos que a mediados de 2010 sufrieron los bonos gubernamentales, desembocaron en las crisis financieras de países como Grecia, Irlanda y Portugal. El desarrollo y la puesta en marcha tardía de los Mecanismos Europeos de Estabilización Monetaria15

${ }^{15}$ Organismo perteneciente a los diecisiete países integrantes de la Eurozona [Alemania, Austria, Bélgica, Chipre, Eslovaquia, Eslovenia, España, 
en mayo del 2010 completaron un escenario que originó una recesión económica desde el segundo semestre de 2011 y sigue en el 2012 (véase gráfica 6).

7. Segunda crisis bancaria europea (2011): a partir de las tenencias de deudas soberanas, el sistema bancario europeo inició un proceso hacia la consolidación de las entidades financieras no bancarias. El proceso para revertir la crisis bancaria mediante la política monetaria emitida por el BCE se expresa en

[...] un plan que fortalece las bases bancarias de capital para reforzar su posición en los mercados financieros, aun cuando este no sea un proceso fácil. Existen tres opciones para que los bancos eleven los promedios de capital solicitado por la Autoridad Bancaria Europea: aumentar sus niveles de capital, vender activos, o reducir el crédito a la economía real.

La primera opción es mejor que la segunda, y la segunda es mejor que la tercera. Sin embargo, elevar los niveles de capital en mercados deprimidos es costoso debido a la resistencia por parte de los accionistas. La venta de activos no es prioritaria y la reducción del crédito a la economía real sería catastrófica. Por tanto, las autoridades públicas deben amortiguar el impacto sobre la economía real y los bancos, considerando la restricción de los dividendos y las compensaciones para fortalecer los mecanismos de contención. ${ }^{16}$ [Draghi, 2011: 1-2].

8. Credit crunch en euros (segundo semestre 2011-primer semestre 2012): la segunda crisis bancaria atemorizó a los

Estonia, Finlandia, Francia, Grecia, Holanda, Italia, Irlanda, Luxemburgo, Malta y Portugal].

${ }^{16}$ Traducción propia. 
banqueros frente a las operaciones interbancarias y se repitió, esta vez en euros, lo que había ocurrido en dólares en la segunda mitad del 2008 y parte del 2009. Los bancos cerraron sus ventanillas de crédito interbancario. La contracción de euros en los mercados bancarios caracterizó la segunda mitad de 2011 e impactó sobre el precio del euro en dólares. Las instituciones no bancarias redujeron sus créditos 35\% en términos netos en el periodo julio 2011-enero 2012. Los préstamos a los hogares para la adquisición de vivienda se contrajeron 29\%, mientras el crédito al consumo se redujo en 13\% [BCE, 2012].

El endurecimiento neto de los estándares de crédito ha sido explicado por la banca en función al entorno adverso que muestra el debilitamiento en las expectativas de crecimiento económico, conforme a las crisis soberanas, lo cual socavó la posición financiera del sector bancario. Las condiciones restrictivas en el crédito y las altas tasas de interés en los préstamos a sociedades no financieras y hogares ha fomentado un entorno de ajuste del consumo en la región europea, incluidas las naciones más grandes, excepto Alemania [BCE, 2012].

La inyección monetaria en la región se llevó a cabo mediante subastas a interés fijo, con la definición de dichas tasas con base en las operaciones principales de financiamiento [BCE, 2011]. Como en el caso de Estados Unidos, la tasa de interés cobrada a los bancos está por debajo de la tasa de inflación. Estas son operaciones de restructuración de deudas interbancarias que pueden ser saldadas después de un año. 
Cuadro 5. Financiamiento a largo plazo con opción de amortización anticipada un año posterior, BCE

\begin{tabular}{cccccc}
\hline $\begin{array}{c}\text { Anuncio } \\
\text { delafecha }\end{array}$ & $\begin{array}{c}\text { Asignación } \\
\text { delafecha }\end{array}$ & $\begin{array}{c}\text { Fechade } \\
\text { liquidación }\end{array}$ & $\begin{array}{c}\text { Primera } \\
\text { fechade } \\
\text { amortización } \\
\text { anticipada }\end{array}$ & $\begin{array}{c}\text { Fechade } \\
\text { vencimiento }\end{array}$ & Madurez \\
\hline 20 dic.2011 & 21 dic.2011 & 22 dic. 2011 & 30 ene.2013 & 29 ene.2015 & 1134 días \\
28 feb.2012 & 29 feb.2012 & 1 mar.2012 & 27feb.2013 & 26feb.2015 & 1092 días \\
\hline
\end{tabular}

BCE, 2011. Elaborado por Francisco Josué Martínez Cervantes, proyecto OBELA, IIEC UNAM.

LA RECONFIGURACIÓN DEL SISTEMA CAPITALISTA DE PRODUCCIÓN.

RECUPERANDO LA MEMORIA HISTÓRICA

El panorama actual que prevalece en los países desarrollados formó parte de un proceso que modificó estructuralmente las economías en desarrollo a partir de la década de los años setenta. Fue Chile, tras el golpe militar que derrocó al gobierno del presidente democráticamente electo Salvador Allende, el país laboratorio que recibió la primera terapia del shock [Klein, 2010]. La caída de las tasas de ganancia industriales en naciones como Estados Unidos, Alemania, Francia y Gran Bretaña a mediados de la década de los sesenta, llevó a la modificación del papel del Estado, a la muerte del keynesianismo, y al surgimiento de nuevas políticas de libre mercado hayekianas de la escuela de Chicago. El deterioro del patrón técnico basado en el motor de combustión se expresó en bajas en la productividad del trabajo, con una producción anual en 
descenso en relación con el stock de capital fijo [Duménil y Lévy, 2002; Morera, 2012].

La implantación de un nuevo paradigma tecno-económico cimentado en la informática, desarrollado por las tecnologías de la información y la comunicación, transformó el carácter precedente de la actividad económica [Pérez, 2004]. El relevo en el patrón tecnológico bajo la nueva forma de organización expulsó a la fuerza de trabajo en función del proceso de transición propio de la revolución tecnológica, el cual prácticamente no requiere fuerza de trabajo individual viva sino trabajo socialmente acumulado, restructurando las relaciones capitalistas a partir de la flexibilización, individualización y precarización del trabajo [Castells, 2006; Quijano, 2010].

Los ajustes estructurales que enfatizan la propiedad privada y los aspectos financieros en consonancia con el catálogo neoliberal, fueron realizados en la región latinoamericana por medio de las disposiciones del fmı en el contexto de la crisis de la deuda en la década de los años ochenta [Williamson, 1990]. La desregulación de la actividad económica, la apertura comercial, la privatización de empresas paraestatales, la movilidad de capitales y la liberalización financiera caracterizaron este proceso y conllevaron la autonomía de la banca central, la libre fijación de la tasa de interés, la privatización de la banca, así como el fomento de los mercados de valores y la liberalización del movimiento de capitales. Estas políticas fueron luego selladas mediante los tratados de libre comercio con Estados Unidos y la Unión Europea.

La introducción de la desregulación financiera ha fomentado la volatilidad en los mercados cambiarios, de va- 
lores y de materias primas con efectos sobre las economías nacionales, dependientes del contexto internacional, tales como Japón (1990 y en adelante), México (1994), Hong Kong, Singapur, Corea del Sur y Taiwán (1997), Rusia (1998), Brasil (1998-1999), Argentina (2001), Estados Unidos (2001, y a partir del 2008) y Europa (a partir del 2010).

FINANCIARIZACIÓN DE LA ECONOMÍA: LA DEUDA ESTADOUNIDENSE Y LA DEPRECIACIÓN DEL DÓLAR

La financiarización de la economía es definida por Pérez [2004] como un proceso agudizado por una crisis general de la productividad conforme al agotamiento del patrón tecno-económico, el cual ha consolidado un aumento de las ganancias financieras en el PIB. Las empresas trasnacionales (ETN) y la gran banca (BT) tienen utilidades que surgen de sus actividades fuera de las fronteras de las economías maduras. Las utilidades de estas, por razón del outsourcing no inciden en el crecimiento económico, en la generación de empleo o la mejora de la distribución del ingreso de dichas economías, pero sí en su cotización en bolsa.

Al contrario, como muestra Palma [2009], el ingreso se ha concentrado en el mundo en general y la participación de los salarios en el PIB se ha contraído. Empero, el consumo crece y lo hace a partir de una expansión del crédito que lleva a un contrasentido. El límite de la expansión del crédito es la imposibilidad de su devolución por falta de empleo y salarios, como se vio en la primera crisis bancaria de 2007-2008. Los 800 bancos medianos y pequeños que han quebrado en Estados Unidos desde el año 2009 has- 
ta el 2012 lo han hecho por este problema. ${ }^{17}$ Es el mismo asunto que se aprecia en España con las Cajas. El consumo que creció a partir del crédito en las dos décadas pasadas ha comenzado a contraerse. Por eso existe una crisis de largo horizonte en las economías maduras, precipitándose las quiebras bancarias, de dos anuales, a 330 anuales entre enero del 2009 y mediados del 2012.

La moderna banca trasnacional (BTN) en un mercado financiero global desregulado y/o autorregulado, ha llegado al paroxismo, cuando quedan 30 instituciones financieras significativas en el mundo que son rescatadas cada vez que se encuentran en peligro, con el argumento de que son demasiado grandes para quebrar. Con las tasas de interés interbancarias europeas, estadounidenses y japonesas cercanas a cero, e incluso negativas en términos reales, los bancos prestan fuera de la zona de las economías maduras porque es más rentable. Por ejemplo, mientras en España en el 2012 los préstamos de nómina del Banco Bilbao Vizcaya Argentaria (BBVA) fueron a tasa de interés nominal de $6.31 \%{ }^{18}$ y la inflación era de $2.6 \%,{ }^{19}$ dejando una tasa de interés real de 3.7\%; en México, BBVA Bancomer prestaba a $27.5 \%{ }^{20}$ prome-

${ }^{17}$ FDIC. Disponible en: http://www2.fdic.gov/hsob/hsobRpt.asp [Consulta: 30 de julio, 2012].

18 Disponible en: http://www.mejorescuentascorrientes.com/cuentanomina-bbva/ [Consulta: 30 de noviembre de 2012].

19 Disponible en: http://es.global-rates.com/estadisticas-economicas/ inflacion/indice-de-precios-al-consumo/ipc/espana.aspx [Consulta: 30 de noviembre de 2012].

20 Disponible en: http://www.losprestamospersonales.com.mx/creditonomina-de-bancomer/ [Consulta: 30 de noviembre de 2012]. 
dio (entre $18 \%$ y $37 \%$ ), siendo la inflación de $4.3 \%,{ }^{21}$ es decir, a una tasa de interés real de $24.2 \%$. La diferencial de intereses reales es de $21.5 \%$. Esto explica movimientos masivos de capitales de corto plazo interbancario hacia los mercados emergentes, con el efecto del mismo sobre la acumulación de reservas internacionales y la apreciación de las monedas en los mercados emergentes.

Como medida dentro de la financiarización, el gobierno estadounidense asumió parte del riesgo de la deuda "tóxica" y el rescate bancario mediante los QE I, II y III, que en última instancia, generó una burbuja especulativa [Lara Cortés, 2009]. Desde un enfoque estructural, esto muestra las contradicciones sistémicas de la economía estadounidense manifestadas primordialmente en el desequilibrio de la cuenta corriente y en su forma de financiamiento, lo que sumado al aumento en los precios de las materias primas y la energía ha generado tensiones de liquidez internacional. La banca privada comercial y de inversión expropió parte de los ingresos de los trabajadores y de otros individuos de la sociedad por medio de los recursos e instrumentos financieros acreditados alrededor del mundo para concentrarlos en las economías líderes [Lapavitsas, 2011].

El stock de bonos del tesoro estadounidense creció desde casi 2.5 billones de dólares en marzo 2000 a casi 3.5 billones en junio 2007. En el mismo lapso las posesiones de los bancos centrales extranjeros en tales bonos aumentaron desde 0.5 billones de dólares a 1.5 billones de dólares [Lara Cortés, 2009: 10].

${ }^{21}$ Disponible en http://es.global-rates.com/estadisticas-economicas/inflacion/indice-de-precios-al-consumo/ipc/mexico.aspx [Consulta: 30 de noviembre de 2012]. 
Lo interesante es que el manejo crediticio mediante una tasa de interés cercana a cero, más los rescates bancarios y las inyecciones de liquidez para contrapesar el credit crunch en dólares del 2009 y en euros del 2011 han trasladado las burbujas especulativas a otras partes del mundo. Los precios por metro cuadrado de los bienes raíces entre distintas ciudades se asemejan y comienzan a ser comparables a los precios de los países ricos, alejándose de la referencia conocida del ingreso per cápita y de los ingresos mensuales promedio dentro de cada economía. Las bolsas de valores están en auge y los tipos de cambio sobreapreciados.

LA GUERRA Y LA REACTIVACIÓN

El traslado del gasto público hacia el incremento en el gasto militar debería tener más impacto que el realizado hacia un mayor gasto civil, dado que el primero tiene más eslabonamientos y un multiplicador del gasto y la inversión más significativo. Pero eso parece haber cambiado en la primera década del siglo transcurrido, de modo que la activación del gasto militar de Estados Unidos no se refleja en el crecimiento del PIB. Por tanto, la nueva racionalidad de la guerra en este contexto no se encuentra en el arrastre económico sino en el negocio y la ganancia [Ugarteche, 2012b]. Detrás está la doctrina política llamada del "nuevo siglo estadounidense" construida por los asesores de Bush entre 1998 y 2008. Las guerras no hay que ganarlas, sino tenerlas y que se perpetúen, utilizando ejércitos privados, de forma que sean rentables. Los problemas de Medio Oriente, por ejemplo, son el reflejo de 
esto. A más guerra en la región, más altos los precios del petróleo, lo que es bueno para las ganancias, aunque sea malo para la inflación mundial y el crecimiento del PIB. Desde 1990 ha habido embargos petroleros a los países productores más importantes, uno tras otro, lo que ha garantizado precios altos sin que impacten sobre la política de los países afectados. Es decir, que el objeto de dicha medida no está en la política sino en el efecto sobre los precios internacionales.

Para la economía de Estados Unidos, la correlación entre crecimiento del PIB e incremento del gasto en defensa es inversa en la década del dos mil (véase gráfica 6). Es decir, a

Gráfica 6. Tasa de crecimiento del PIB y del gasto en defensa de Estados Unidos, 2000-2012 III

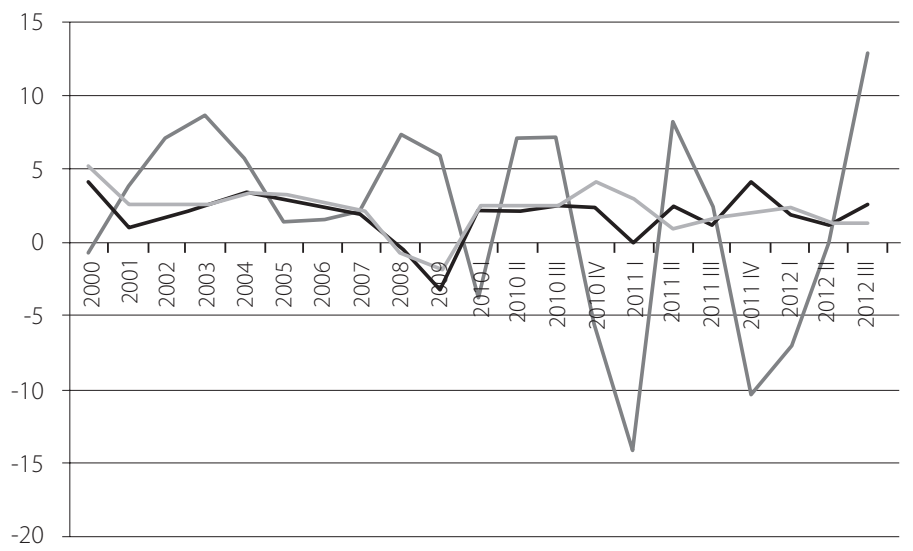

_ Producto interno bruto

—_ Defensa nacional

- Gastos de consumo personales

BEA. Disponible en http://www.bea.gov/iTable/iTable.cfm?ReqID=13\&step=1 [Consulta: 1 de diciembre de 2012]. Elaboración propia. 
más guerra menos crecimiento económico o, a menos gasto en defensa, más crecimiento económico, de modo que la nueva lógica económica aparentemente se reduce a dos ramas esenciales: la financiera y la militar, aunque ninguna parece activar la economía real. Las ganancias crecientes de estos sectores, empero, no se reflejan en un mayor crecimiento del PIB que sigue fuertemente atado al consumo, pero sí en las bolsas de valores saludables y en la concentración del ingreso.

Una explicación de la resiliencia del crecimiento de las economías emergentes, contrario al estancamiento económico de las economías maduras, se puede observar en la sustitución de mercados y la pérdida de gravitación del mercado de Estados Unidos para el nuevo G7 durante la primera década del siglo. China redujo a solo 10\% su comercio exportador con Estados Unidos en el segundo lustro de la década inicial del siglo. De los países en la lista del nuevo G7, es el que mantiene mayor relación exportadora con Estados Unidos. Los demás países lo han reducido a un dígito. Todos han sustituido mercados: Brasil lo aminoró a casi un tercio de lo que era, de 24\% a 9\%; Indonesia de 13\% a $9 \%$. Rusia, que tiene poca relación, lo contrajo de $4 \%$ a 3\%; la India viene en descenso marcado y Turquía casi ha sacado a Estados Unidos de su lista de contrapartes. Por otro lado, América Latina representa para Brasil el doble que Estados Unidos como mercado. Para los demás es un mercado pequeño, aunque muy dinámico (véase cuadro 6).

La Unión Europea se ha mantenido como el mercado privilegiado del nuevo G7, por lo que dicho comercio se verá afectado por la prolongada recesión europea y obliga- 


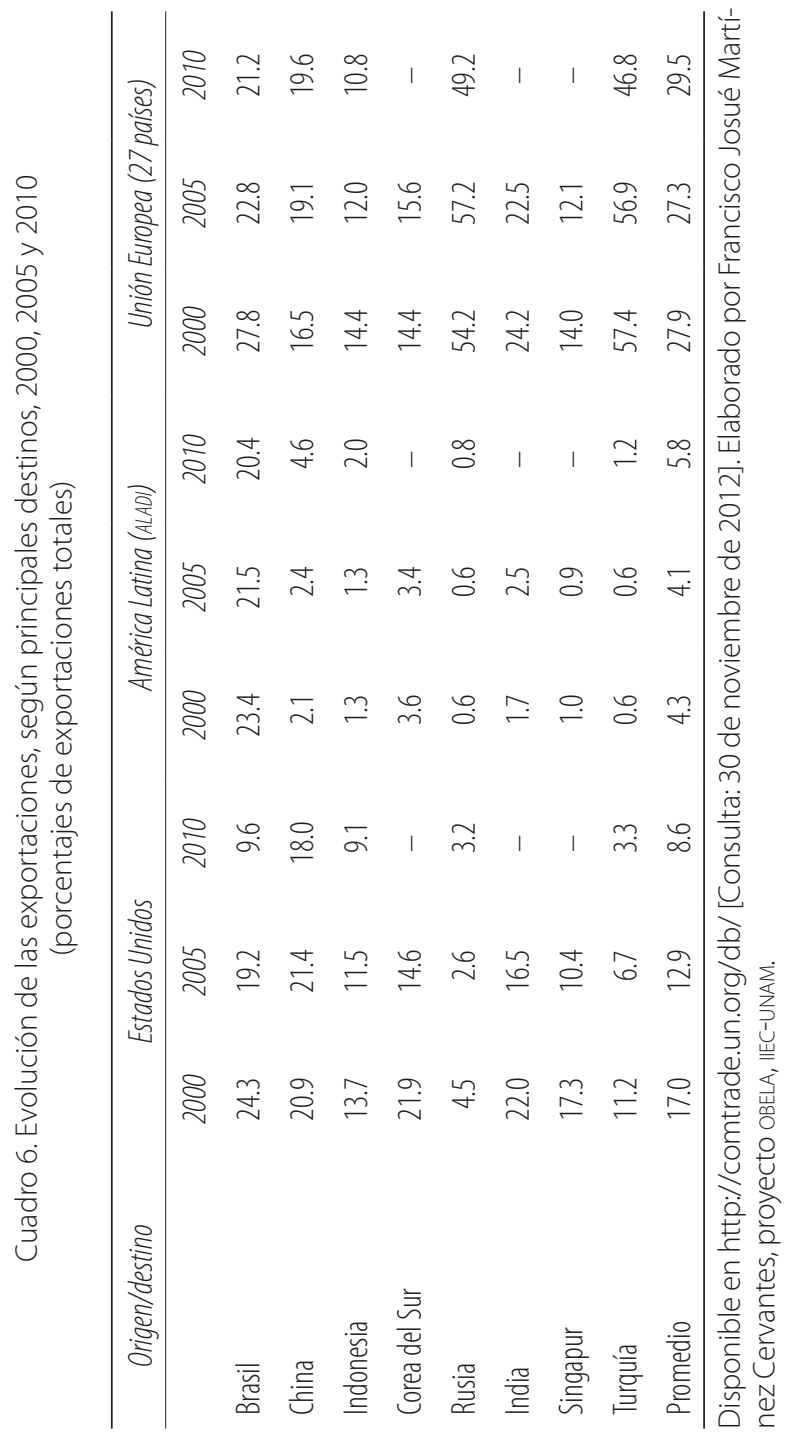


rá a un segundo ajuste de mercados. El mercado que más ha absorbido lo que Estados Unidos ha perdido es el asiático, que es sin duda el más dinámico. Visto a la inversa: Brasil le compra menos a Estados Unidos y a América Latina, así como a la Unión Europea, dejándole a Asia el crecimiento como proveedor mundial; China, Indonesia, Corea del Sury Turquía compran relativamente menos de Estados Unidos y de la Unión Europea y más de América Latina y de los propios asiáticos. Rusia adquiere más a Europa y América Latina y mantiene a Asia relativamente estable frente a Estados Unidos en contracción.

El desplazamiento del poder global en curso se puede observar en la influencia de los países en la economía mundial. Los integrantes del nuevo G-7 gravitan la mitad en el PIB que los países, del antiguo G-7. Sus indicadores económicos muestran 2.8 veces más reservas internacionales; crecen cinco veces más rápido a partir del cambio de siglo; tienen una deuda pública que es $34 \%$ de la de los desarrollados; una deuda externa que es $15 \%$ de los viejos países; y tienen un ingreso por habitante que es la mitad de los del G-7 anterior. En 16 años, si se mantienen las tasas de crecimiento promedio de la primera década, estas catorce economías convergerían en su ingreso total. Un alza en las tasas de interés internacionales morigerará la tendencia pero no la cambiará.

Las proyecciones realizadas por el fmi acerca del devenir de estas economías dejan en claro que para el año 2017 China será la economía líder, seguida de Estados Unidos, la India, Japón, Alemania, Rusia y Brasil. Esto implica que se verá una lucha encarnizada del G-7 por no perder el control del mundo, y que Estados Unidos tendrá que hacer lo posible por impedir que los BRICs cobren un poder político 
y militar proporcional a su poder económico y financiero. Más aún, Estados Unidos y Europa harán lo posible por recuperar el control económico global y alejar a las economías emergentes del camino emprendido.

A MODO DE CONCLUSIÓN

El orden mundial surgido tras la segunda guerra parece haber llegado a su fin. Estamos ante el fin de la Pax Americana y de las instituciones multilaterales que la garantizaban. Ni la Organización Mundial del Comercio funciona, ni el Consejo de Seguridad de la Organización de las Naciones Unidas (véase el caso de la invasión injustificada a Irak, o el tratamiento de Libia, o el conflicto palestino-israelí), ni las instituciones financieras internacionales que han servido sobre todo de instrumento de política exterior de Estados Unidos. Sin embargo, conforme los problemas se han agudizado por la crisis, se observa un retorno al uso de esa institucionalidad inoperante, sobre todo para fortalecer el poder del sector financiero, esencialmente anglosajón. De esta forma, el capital financiero va ganando posiciones de la mano de los gobiernos de Estados Unidos y Gran Bretaña, aunque en apariencia estén hegemónicamente debilitados. A esto se refieren tanto Katz como Villarán y Schuldt [2012] en sus trabajos.

Lo anterior provoca al menos tres tipos de crisis que invaden al mundo. La primera de empleo, relacionada con las economías maduras y sus dificultades. En Estados Unidos y Europa no habrá nuevo empleo creciente en la segunda 
Cuadro 7. Indicadores comparados, diciembre 2011

\begin{tabular}{lccc}
\hline & $\begin{array}{c}\text { Reservas } \\
\text { internacionales } \\
(\text { mmd) }\end{array}$ & $\begin{array}{c}\text { \% Deudapública* } \\
\text { PIB }\end{array}$ & $\begin{array}{c}\text { \% Deuda } \\
\text { externa**/PiB }\end{array}$ \\
\hline Estados Unidos & 120.8 & 97.6 & 97.5 \\
Canadá & 57.9 & 85.4 & 68.0 \\
Inglaterra & 69.9 & 90.0 & 404.5 \\
Alemania & 59.0 & 86.9 & 157.5 \\
Francia & 42.9 & 98.6 & 203.1 \\
Italia & 43.4 & 127.7 & 122.3 \\
Japón & 1109.9 & 229.6 & 46.3 \\
Viejo G-7 & 1503.80 & 116.5 & 157.0 \\
China & 2825.4 & 25.8 & 9.5 \\
Brasil & 309.1 & 64.9 & 16.1 \\
Rusia & 400.5 & 12.0 & 28.0 \\
India & 239.3 & 67.0 & 15.7 \\
Indonesia & 94.0 & 24.5 & 22.1 \\
Corea del Sur & 268.4 & 34.2 & 35.6 \\
Turquía & 69.1 & 39.3 & 39.7 \\
Nuevo G-7 & 4205.70 & 38.2 & 23.8 \\
\hline Reseras & & &
\end{tabular}

Reservas internacionales: Banco Mundial y BEA

Deuda pública: OCDE Y FMI, CIA Factbook.

Deuda externa: FMI, CIA, Departamento del Tesoro.

** Deuda pública es deuda en moneda nacional.

*** Deuda externa incluye deuda pública y privada en moneda extranjera. Cuadro elaborado por Francisco Josué Martínez Cervantes, proyecto oBELAIIEC-UNAM. 
Cuadro 8. Tamaño y dinámica del PIB

\begin{tabular}{lccc}
\hline & $\begin{array}{c}\text { PIB total 2011 } \\
\text { (billones de dólares) }\end{array}$ & PIB per cápita 2011 & $\begin{array}{c}\text { Tasa promedio de } \\
\text { crecimiento del PIB } \\
\text { 2002-2011 }\end{array}$ \\
\hline Estados Unidos & 13315.20 & 42733.00 & 1.63 \\
Canadá & 1531.50 & 44412.50 & 1.96 \\
Gran Bretaña & 2145.00 & 34243.30 & 1.46 \\
Alemania & 3149.80 & 38540.80 & 1.11 \\
Francia & 2446.20 & 37383.40 & 1.11 \\
Italia & 1936.10 & 31859.60 & 0.25 \\
Japón & 5175.70 & 40493.30 & 0.67 \\
Viejo G-7 & 4242.80 & 38523.70 & 1.17 \\
China & 6456.00 & 4803.10 & 10.59 \\
Brasil & 2184.80 & 11109.80 & 3.78 \\
Rusia & 1638.80 & 11546.80 & 4.83 \\
India & 1630.20 & 1313.10 & 7.66 \\
Indonesia & 747.00 & 3082.80 & 5.51 \\
Corea del Sur & 984.70 & 19781.50 & 4.14 \\
Turquía & 682.00 & 9261.10 & 5.42 \\
Nuevo G-7 & 2046.20 & 8699.70 & 5.99 \\
\hline
\end{tabular}

FMI. Cuadro elaborado por Francisco Josué Martínez Cervantes, proyecto OBELA-IIEC-UNAM. 
década del siglo xxı, sino que el empleo se ha estancado, dejando a nuevas generaciones sin ingreso al mercado de trabajo. Esto suma la mitad de la población joven en algunos países. En el otro extremo, debido a la crisis en Estados Unidos, 39\% de los hogares habían quedado desempleados o estaban en paro, tenían un valor patrimonial negativo, o habían caído en mora en los pagos cotidianos entre noviembre del 2008 y abril del 2010, [Hurd y Rohwedder 2010]. Para los jubilados, este problema se acentúa [Whitehouse, 2010]. La consecuencia de todo lo anterior es una década sin crecimiento económico y con malestar social en las economías que fueron el motor de la economía mundial desde 1500 hasta el año 2007. En el campo social, la crisis se expresa en la protesta del grupo de Los Indignados, que ocupó Wall Street, 15-M, etc. Por tanto, se avizora más conflicto social en lOS PRAE y luego un cambio en la estructura de poder global y migración inversa, análoga a la de fines del siglo xIx.

La segunda crisis gira en torno a los conflictos medioambientales. En Asia, África y América Latina se pueden observar movimientos que manifiestan su derecho al respeto de la naturaleza, los pueblos americanos fundamentando su rebeldía mediante la noción andina del buen vivir (Sumak kawsay o Suma qamaña) en oposición a la penetración de empresas mineras y petroleras que depredan el ambiente y pagan con contaminación, y a la lógica de la economía extractivista.

El tercer tipo de conflicto social es el de los migrantes que tratan de llegar al mundo desarrollado. Con la contracción económica, la xenofobia ha crecido, y las represalias contra trabajadores extranjeros no documentados ha lle- 
vado a extremos de militarización y violencia nunca antes vistos, salvo en los años treinta. Solo en la frontera entre México y Estados Unidos se han dado 5747 muertes en menos de una década. ${ }^{22}$ Esto es 82 veces más muertos al año que en la historia del Muro de Berlín en veintiocho años (1961-1989). A su vez, el Mediterráneo tiene tres veces más muertos que la frontera norteamericana [ACNUR, 2012].

No existe salida de la crisis capitalista sin la consolidación de condiciones para un nuevo orden mundial y el ingreso a una nueva época. Se requieren formas de producción y consumo ecológicamente sustentables, sin armamento nuclear, y a la par con la construcción de vínculos sociales cuyos cimientos sean los principios de redistribución relacionados con la equidad y el principio del reconocimiento, entendido este como la aceptación de las diferencias [Santos, 2009]. De otro modo, será irrelevante el hecho de que entremos en una nueva era.

${ }^{22}$ Disponible en http://www.telemundo33.com/noticia/2011/11/01/308946muro-fronterizo-cede-altar-dia-muertos.html [Consulta: 30 de julio de 2012]. 


\section{DEL SISTEMA FINANCIERO \\ AL COMPLEJO FINANCIERO BANCARIO}

INTRODUCCIÓN

En toda gran crisis, se produce un fuerte salto institucional financiero y bancario relacionado con la necesidad de resolver el riesgo sistémico existente y minimizarlo en el futuro. La evolución del sistema financiero internacional ha respondido a las dificultades que en cada etapa se han debido enfrentar para resolver los problemas de riesgo.

Eso se vio claramente en las crisis de los años cercanos a 1870 y la década de los años treinta del siglo pasado. Por ejemplo, en los años treinta, tras el desplome financiero de octubre de 1929, quedó en evidencia que el patrón oro había pasado a ser obsoleto y las regulaciones bancarias eran inadecuadas. De esa crisis salieron las ideas para instaurar el patrón dólar/oro, los conceptos del Fondo de Estabilización Cambiario y del acuerdo de Bretton Woods sobre tipos de cambio fijos y un fondo para asegurarlo. ${ }^{23}$

${ }^{23}$ Los tipos de cambio fijos anclados en la relación dólar-oro a 35.70 dólares la onza se establecieron tras el Gold Reserve Act de 1934 y el acuerdo liderado por Estados Unidos con Francia y Gran Bretaña para mantener el tipo de cambio estable en 1935 [Bordo \& Schwartz, 2001] que se mantuvo hasta agosto de 1971 [Elwell, 2011 y Garber, 1991]. 
Tras la liberalización vino el auge de precios de las materias primas y con ello la acumulación de reservas bancarias, que llevó al auge de créditos internacionales y la necesidad de liberalizar las cuentas de capitales, con lo que el sector financiero en Estados Unidos dobló las actividades financieras agregadas en el PIB entre 1970 y 2010, de 15\% a 31\% (cuadro 1). Al mismo tiempo, el problema de la falta de rentabilidad del capital productivo obligó a llevar un manejo más eficiente de los aspectos financieros de la empresa, lo que determinó que lo financiero fuera lo más importante y lo productivo se subordinara a ello.

En este contexto, desde 1980 se fue quedando atrás el concepto de sistema, mientras se consolidaba la noción de complejo, en el sentido que le dio Eisenhower. Parafraseando su discurso sobre el complejo militar industrial se podría decir que:

La conjunción de un establishment financiero inmenso y una industria bancaria grande es nueva en la experiencia americana. La influencia total -económico, política, aun espiritual-es sentida en cada ciudad, cada edificio del órgano legislativo de un estado, cada oficina del Gobierno Federal. Reconocemos la necesidad imperativa de este desarrollo. Sin embargo, no debemos dejar de comprender sus graves implicaciones. Nuestro trabajo, recursos y modo de vida están implicados; como lo está la estructura misma de nuestra sociedad.

En los consejos de gobierno, debemos de protegernos contra la adquisición de influencia injustificada del complejo financiero bancario. El potencial para el aumento desastroso de poder inapropiado existe y persistirá. Nunca debemos dejar 
al peso de esta combinación poner en peligro nuestros derechos o procesos democráticos.

Nosotros no deberíamos dar nada por sentado. Sólo una ciudadanía despierta y bien informada puede obligar a tener la combinación apropiada de la enorme maquinaria financiera y bancaria con nuestros métodos pacíficos y objetivos, de modo que la seguridad y la libertad puedan prosperar juntas.

Próximas a, y en gran parte responsable de los cambios amplios de nuestra postura financiera bancaria, han sido las innovaciones financieras de las décadas recientes. En esta revolución, la investigación es un hecho central; también se ha vuelto más formalizada, compleja, y costosa. Una parte regularmente creciente es conducida para, por, o bajo la dirección del gobierno federal.

Hoy, el creador solitario, que hace pequeños cambios en su banco, ha sido ensombrecido por los grupos de trabajo de científicos en laboratorios y campos de experimentación. De la misma manera, la universidad libre, históricamente manantial de ideas libres y del descubrimiento científico, ha experimentado una revolución en la conducta de investigación. En parte debido a los enormes gastos implicados, un contrato de la banca se convierte prácticamente en sustituto por la curiosidad intelectual. Por cada vieja pizarra hay ahora cientos de nuevas computadoras.

La perspectiva de dominación de los eruditos nacionales por el empleo bancario, las asignaciones de proyectos, y el poder del dinero está presente y debe de ser considerado con seriedad. 
Aun, teniendo mucho respeto por la investigación científica y el descubrimiento, como nosotros deberíamos, también debemos estar alertas al peligro de que la política pública termine cautiva de una élite bancaria [Eisenhower, 1961].

A partir del año 2007, se puede reconocer que el riesgo sistémico ha crecido acompañado por la insuficiencia de las instituciones e instrumentos existentes para resolverlo. Empero, no se observan cambios significativos en el modus operandi sistémico a pesar de los esfuerzos de Basilea III [BIS, 2010]. Esto obliga a preguntarnos si el sistema financiero en efecto es un sistema, o si ha venido transformándose en complejo bancario, analizando los cambios sobre la gobernanza financiera. El sistema por definición tiene capacidad de cambiar cuando lo requiere. Ese cambio ahora no se observa. El sistema financiero internacional parece haber llegado a un límite. Las instituciones creadas en 1944 dejaron de resolver el problema del riesgo y de la información, mientras que el modo de operar financiero se ha modificado.

Lo que se va a explorar ahora es si estamos ante el surgimiento del complejo financiero bancario, tomando la idea de Harvey [2004]. Harvey sugiere que el complejo es una articulación entre Wall Street-la Reserva Federal-fml. Nosotros queremos argumentar que a partir de la década de los ochenta, y el inicio de la desregulación, el Tesoro de Estados Unidos fue capturado por agentes de los sectores financiero-bancario, y que actúa sobre y define las políticas públicas desde esa óptica y desde allí incide en el fmi. Por otro lado, se sabe que el FED históricamente está dirigido por banqueros comerciales. Por ello no se ha tomado de manera estricta 
el criterio de Harvey y se ha preferido indagar más sobre el complejo bancario.

\section{QUÉ ES UN SISTEMA}

La definición lingüística de sistema es: un "conjunto de reglas o principios sobre una materia racionalmente enlazados entre si" (1ª acepción, RAE, 2001). Otra definición es: un "conjunto de unidades que relacionadas entre sí ordenadamente contribuyen a determinado objeto" (2a acepción, RAE, 2001).

Desde el punto de vista de la segunda acepción, el sistema financiero sería la suma de bancos, fondos de pensiones, de inversión, fideicomisos, bolsas de valores, mercados de commodities y cambiarios y otras instituciones financieras que contribuyen a la creación de los mercados de dinero y de crédito, con el fin de facilitar el traslado de recursos de sectores excedentarios a los deficitarios para dinamizar las inversiones físicas, la producción de bienes y servicios, y el consumo.

Visto desde el conjunto de reglas o principios racionalmente enlazados entre sí, se abre la interrogante de si tener reglas distintas para instituciones que son parte del mismo sistema conlleva racionalidad. Tener bancos "muy grandes para quebrar" junto con bancos que pueden quebrar no es coherente en un sistema. Habría en todo caso un subsistema de bancos "muy grandes para quebrar" y otro de bancos "de tamaño correcto para quebrar". Los dos subsistemas sin embargo no logran sumar un solo sistema porque en uno los funcionarios no temen quebrar y pueden ser 
descuidados en su búsqueda de ganancias; y en el otro, los funcionarios deben ser responsables y actuar con prudencia en su búsqueda de ganancias. Los actores no operan con las mismas reglas ni con la misma racionalidad en estos dos subsistemas, por lo que no constituyen un solo sistema en el sentido lingüístico.

Si se lleva a cabo una revisión de los secretarios del Tesoro de Estados Unidos de 1971 a 2012, se puede observar claramente que a partir de 1979 estos provienen del sector financiero, específicamente de la banca de inversión. G. William Miller es un ejemplo en el que un abogado de bancos comerciales llega a ser miembro de la Junta del Fed de Boston, posteriormente presidente de la Reserva Federal, y luego secretario del Tesoro (véase cuadro 9). Esta última es la etapa del inicio de la desregulación financiera, mediante la ley de Desregulación de Instituciones de Depósito y Control Monetario, emitida en marzo de 1980, cuyo proceso culminó en 1999 con la ley Gramm Leach Bliley. Esto preludia la crisis del año 2007 en adelante. Desde el punto de vista de la actuación directa dentro del Ejecutivo, se puede apreciar que hubo "entrismo" de parte del sector financiero que controla las políticas del Poder Ejecutivo desde la Secretaría del Tesoro.

\section{EL COMPLEJO FINANCIERO BANCARIO}

La noción de complejo es definida por Eisenhower [1961] cuando señala que hay intereses económicos que absorben recursos del Estado para beneficio propio mediante 
Cuadro 9. Secretarios del Tesoro de Estados Unidos 1961 a 2012

\begin{tabular}{|c|c|c|c|}
\hline Secretario del Tesoro & Periodo & Presidente & Procedencia \\
\hline $\begin{array}{l}\text { C. Douglas Dillon, } \\
\text { New Jersey }\end{array}$ & $\begin{array}{l}\text { Ene. 21, } 1961 \text { - Nov. 22, } 1963 \\
\text { Nov. 22, } 1963 \text { - Abr. 1, } 1965\end{array}$ & $\begin{array}{l}\text { Kennedy } \\
\text { L.B. } \\
\text { Johnson }\end{array}$ & $\begin{array}{l}\text { CEO Dillon } \\
\text { Read IB }\end{array}$ \\
\hline Henry H. Fowler, Virginia & Abr. 1, 1965 - Dic. 20, 1968 & $\begin{array}{l}\text { L.B. } \\
\text { Johnson }\end{array}$ & Abogado \\
\hline Joseph W. Barr, Indiana & Dic. 21, 1968 - Ene. 20, 1969 & $\begin{array}{l}\text { L.B. } \\
\text { Johnson }\end{array}$ & $\begin{array}{l}\text { Hombre } \\
\text { de negocios }\end{array}$ \\
\hline David M. Kennedy, Utah & Ene. 22, 1969 - Feb. 11, 1971 & Nixon & $\begin{array}{l}\text { CEO } \\
\text { Continental } \\
\text { Illinois Bank }\end{array}$ \\
\hline John B. Connally, Texas & Feb. 11, 1971 - Jun. 12, 1972 & Nixon & Abogado \\
\hline George P. Shultz, Illinois & Jun. 12, 1972 - May. 8, 1974 & Nixon & Bechtel \\
\hline $\begin{array}{l}\text { William E. Simon, } \\
\text { New Jersey }\end{array}$ & $\begin{array}{l}\text { May. 8, } 1974 \text { - Ago. 9, } 1974 \\
\text { Ago 9, } 1974 \text { - Ene. 20, } 1977\end{array}$ & Nixon Ford & $\begin{array}{l}\text { Hombre } \\
\text { de negocios }\end{array}$ \\
\hline $\begin{array}{l}\text { W. Michael Blumenthal, } \\
\text { Michigan }\end{array}$ & Ene. 23, 1977 - Ago. 4, 1979 & Carter & CEO UNISYS \\
\hline $\begin{array}{l}\text { G. William Miller, } \\
\text { Rhode Island }\end{array}$ & Ago. 6, 1979 - Ene. 20, 1981 & Carter & $\begin{array}{l}\text { Hombre } \\
\text { de negocios, } \\
\text { Presidente de } \\
\text { Fed de Boston } \\
\text { y del FED }\end{array}$ \\
\hline $\begin{array}{l}\text { Donald T. Regan, } \\
\text { New Jersey }\end{array}$ & Ene. 22, 1981 - Feb. 2, 1985 & Reagan & $\begin{array}{l}\text { CEO Merrril } \\
\text { Lynch }\end{array}$ \\
\hline James A. Baker, III, Texas & Feb. 3, 1985 - Ago. 17, 1988 & Reagan & Abogado \\
\hline
\end{tabular}

(Continúa) 
(uadro 9 (continuación)

\begin{tabular}{|c|c|c|c|}
\hline Secretario del Tesoro & Periodo & Presidente & Procedencia \\
\hline $\begin{array}{l}\text { Nicholas F. Brady, } \\
\text { New Jersey }\end{array}$ & $\begin{array}{l}\text { Sep. 16, } 1988 \text { - Ene. 20, } 1989 \\
\text { Ene. 20, } 1989 \text { - Ene. 17, } 1993\end{array}$ & $\begin{array}{l}\text { Reagan } \\
\text { G.H.W. } \\
\text { Bush }\end{array}$ & $\begin{array}{l}\text { CEo Dillon } \\
\text { Read IB }\end{array}$ \\
\hline Lloyd M. Bentsen, Texas & Ene. 22, 1993 - Dic. 22, 1994 & Clinton & $\begin{array}{l}\text { CEo Lincoln } \\
\text { Consolidated } \\
\text { Financial } \\
\text { Services }\end{array}$ \\
\hline $\begin{array}{l}\text { Robert E. Rubin, } \\
\text { Nueva York }\end{array}$ & Ene. 10, 1995 - Jul. 2, 1999 & Clinton & $\begin{array}{l}\text { Co Presidente } \\
\text { Goldman Sachs }\end{array}$ \\
\hline $\begin{array}{l}\text { Lawrence H. Summers, } \\
\text { Massachusetts }\end{array}$ & Jul. 2, 1999 - Ene. 20, 2001 & Clinton & $\begin{array}{l}\text { Asesor sector } \\
\text { financiero y } \\
\text { académico }\end{array}$ \\
\hline $\begin{array}{l}\text { Paul H. O'Neill, } \\
\text { Pennsylvania }\end{array}$ & Ene. 30, 2001 - Dic. 31, 2002 & G.W. Bush & CEO ALCOA \\
\hline John W. Snow, Virginia & Feb. 3, 2003 - Jun. 29, 2006 & G.W. Bush & Abogado \\
\hline $\begin{array}{l}\text { Henry M. Paulson, Jr., } \\
\text { Illinois }\end{array}$ & Jul. 10, 2006 - Ene. 20, 2009 & G.W. Bush & $\begin{array}{l}\text { CEO Goldman } \\
\text { Sachs }\end{array}$ \\
\hline $\begin{array}{l}\text { Timothy F. Geithner, } \\
\text { Nueva York }\end{array}$ & Ene. 26,2009 - Ene. 25, 2013 & Obama & $\begin{array}{l}\text { Funcionario } \\
\text { público, } \\
\text { presidente del } \\
\text { FED de Nueva } \\
\text { York, y del FED. }\end{array}$ \\
\hline
\end{tabular}

Fuente: http://www.treasury.gov/about/history/Pages/edu_history_secretary_index.aspx 
su influencia tanto en la investigación universitaria como en la investigación empresarial. Se conforma una élite que captura las políticas públicas y sesga el manejo del Estado a su favor. Parafraseando a Eisenhower, el complejo une al inmenso establishment financiero con una nueva industria bancaria. Baste recordar que Henry Paulson, ex cEo de Goldman Sachs, en su calidad de secretario del Tesoro obligó a la banca de inversión y a las instituciones financieras no bancarias muy grandes para quebrar que deseaban recibir apoyo público a convertirse en bank holding companies. Lo hizo porque como bancos tienen la protección del FDIc, seguros de depósitos, acceso a la ventanilla de descuentos del FED, y una gama de mecanismos nuevos del FED para otorgarle créditos a la banca. Nada de esto era posible si permanecían como parte del sistema financiero no bancario.

Para determinar si existe o no un complejo bancario en Estados Unidos primero se debe revisar el tamaño de la actividad financiera bancaria en aquel país, y su desarrollo desde que se inició la desregulación financiera, es decir, desde 1971, cuando se estableció el mercado cambiario libre y con él se potenciaron los mercados de commodities y de valores.

Esta revisión se puede hacer de varios modos: medir el tamaño de PIB financiero bancario (cuadro 10); medir los activos financieros en el PIB; y el tamaño del empleo en el sector bancario. Asimismo, revisar el incremento en los trabajos de investigación financieros en el periodo 1980-2010. Por otra parte, para poder observar la incidencia en la política pública se puede revisar la presencia de actores del sector dentro del aparato Ejecutivo y su incidencia dentro del Legislativo estadounidense, junto con la reducción de la regulación pública y el incremento del gasto fiscal destinado a este sector. 
En el cuadro 10 se hace evidente que la actividad financiera en su acepción económica más amplia, que incluye banca comercial, seguros, valores, fondos, bienes raíces y arrendamiento financiero, ha observado una duplicación de su cuantía en el PIB estadounidense entre 1970 y 2010. De manera más específica, la relevancia del sector financiero aumenta en la misma proporción que declina el de la industria manufacturera y el sector comercial. Esto podría indicar que la importancia del sector militar industrial en el PIB de etapas anteriores a 1970 se habría reducido, comparado con la del sector financiero bancario.

[...] El sistema financiero que hemos examinado tiene poca semejanza con el existente en la generación de nuestros padres. Los cambios solo en las tres décadas pasadas han sido notables. Los mercados financieros se han vuelto cada vez más globalizados. La tecnología ha transformado la eficacia, velocidad, y complejidad de instrumentos financieros y transacciones. Hay un acceso más amplio y menores costos de financiación que nunca antes. Y el sector financiero en sí mismo se ha vuelto una fuerza más dominante en nuestra economía. ${ }^{24}$

Cuando se afirma, por ejemplo, que el sector se ha globalizado de manera creciente, se quiere decir que se abrieron las cuentas de capitales en el mundo. Esa fue una decisión tomada y esparcida por el mundo con la ayuda del Banco Mundial y del fmi como parte de las reformas estructurales a partir de una comprensión teórica de lo argumentado

${ }^{24}$ Final Report of the National Commission on the Causes of the Financial and Economic Crisis in the United States, xvi-xvil. Disponible en http:// www.gpo.gov/fdsys/pkg/GPO-FCIC/pdf/GPO-FCIC.pdf Consulta: 08 febrero 2013. 
Cuadro 10

Producto Interno Bruto por producto, Estados Unidos.

(porcentaje)

\begin{tabular}{lccccccc}
\hline \multicolumn{1}{c}{ Transacción } & 1970 & 1980 & 1990 & 2000 & 2009 & 2010 \\
\hline PIB & 100.0 & 100.0 & 100.0 & 100.0 & 100.0 & 100.0 \\
$\begin{array}{l}\text { Valor agregado bruto a precios } \\
\text { básicos, total actividad }\end{array}$ & 90.94 & 91.25 & 92.58 & 93.31 & 93.09 & 93.10 \\
$\begin{array}{l}\text { Agricultura, caza y pesca } \\
\text { Industria incluyendo energía }\end{array}$ & 3.12 & 26.63 & 1.92 & 1.11 & 1.03 & 1.10 \\
$\begin{array}{l}\text { Construcción } \\
\text { Ventas al por mayor y menor, }\end{array}$ & 4.75 & 25.89 & 21.72 & 17.20 & 14.40 & 15.13 \\
$\begin{array}{l}\text { reparaciones; hotelería y } \\
\text { restauración, transporte }\end{array}$ & 21.43 & 20.99 & 20.25 & 18.70 & 16.92 & 16.95 \\
$\begin{array}{l}\text { Intermediación financiera; bienes } \\
\text { raíces, arrendamiento financiero }\end{array}$ & 15.95 & 17.98 & 22.95 & 29.55 & 31.56 & 31.21 \\
y otros & & & & & & \\
$\begin{array}{l}\text { Otras actividades de servicios } \\
\text { Impuestos menos subsidios en }\end{array}$ & 19.46 & 19.26 & 21.49 & 22.07 & 25.31 & 25.22 \\
$\begin{array}{l}\text { productos } \\
\text { Discrepancia estadística }\end{array}$ & 8.41 & 7.15 & 6.89 & 6.69 & 6.91 & 6.90 \\
\hline
\end{tabular}

Elaboración propia. OCDE, National Accounts.

por Mackinnon y Shaw y más tarde por los teóricos de los mercados eficientes, ya señalados. Estos autores sostuvieron que liberalizando las tasas de interés se alimentaría más inversión y crecimiento económico, que estaba entonces distorsionado por la represión y la restricción financiera. Se introdujo con eso inestabilidad en la economía mundial por medio de mercados cambiarios inestables. La posición 
de Estados Unidos en el fmi está defendida por el Tesoro, de manera que ese es el canal político de transmisión.

El resultado fue que en Estados Unidos se abrió un acceso más amplio al crédito a menores costos, algo que no ocurrió en el resto del mundo, donde se trasladan los capitales en busca de la rentabilidad perdida en dicho país. Es decir, que no es posible observar lo que ocurre con el sector financiero dentro de Estados Unidos sin que en algún momento los efectos se reflejen en el resto del mundo. El informe reconoce que el sector financiero es mucho más dominante. Las cifras revelan que constituye el sector dominante en Estados Unidos expresando más de un tercio del PIB de dicho país, lo que es doble que el sector productivo.

Entre los años 2000 y 2010 el peso del sector creció, lo que en una economía que tuvo muy bajo crecimiento y que se contrajo en el año 2009 resulta paradójico, ya que su peso es mayor tras la crisis iniciada por el sector financiero que previo a la crisis. Puesto de otra manera, la crisis financiera que impactó sobre toda la economía de Estados Unidos y que contagió al resto del mundo no afectó de manera significativa al sector financiero de ese país.

Entre el año 1978 y 2007 los activos llevados por el sector financiero en su sentido más amplio crecieron de tres billones de dólares a 36 billones de dólares, más del doble del PIB de Estados Unidos en 2007.25 En el 2005, los 10 bancos comerciales más grandes de Estados Unidos concentraban 55\% de los activos del sector financiero, más del doble que

${ }^{25}$ National Commission on the Causes of the Financial and Economic Crisis, p. xvii. Disponible en http://www.gpo.gov/fdsys/pkg/GPO-FCIC/ pdf/GPO-FCIC.pdf Consulta: 08 febrero 2013. 
en 1990 según la National Commission on the Causes of the Financial and Economic Crisis. En el 2012 esa cifra creció a 73\%, como se verá más adelante, tras la pérdida de 11 billones de dólares según la misma Comisión.

La ausencia de impacto de la crisis en el PIB del sector tiene que ver con la manera como este ha defendido su actuación y la compra de activos devaluados, al mismo tiempo que la inyección de recursos públicos y crédito del FED, beneficio que ningún otro sector tuvo en el mismo periodo y que ningún otro sector ha tenido nunca. Esto habla de una división dentro del sector financiero. Hay quienes son parte del complejo y los que no lo son. Los bancos que son muy grandes para quebrar son parte del complejo, los que tienen el tamaño correcto para quebrar, no pertenecen a él. Eso divide a los banqueros en aquellos responsables entre los de tamaño correcto para quebrar, y banqueros muy arriesgados o abiertamente avaros, entre los que siempre serán rescatados.

Al observar con detalle dentro del sector financiero (véase cuadro 11), su participacion en el pIB de Estados Unidos, llama la atención el poco peso de los impuestos dentro del valor agregado. Para la suma de todos los subsectores del sector financiero, la participación de impuestos es alrededor de $5 \%$ de la contribución total. Siendo el peso 31\% del PIB y la participación 5\%; el aporte a la presión fiscal del país es de 1.6\% del PIB. La media de la presión fiscal del país a todos los niveles (federal, estatal y municipal) es de $24 \%$ del PIB según la OCDE. Es decir, que el aporte fiscal del sector financiero que expresa un tercio del PIB es de solo 6.6\% de lo que ingresó al Fisco por todos los conceptos en todos los niveles. Esa es una construcción lograda mediante acciones en el Poder Legislativo con el fin de evitar pagar impuestos me- 
diante la promoción de paraísos financieros. Los paraísos financieros también son conocidos como paraísos fiscales [Shaxson, 2012].

EL COMPLEJO BANCARIO Y LA PRIVATIZACIÓN DE LA GOBERNANZA FINANCIERA

El modus operandi del complejo bancario yace en la bilateralización y privatización del sector financiero, dado el énfasis de las instituciones financieras internacionales en la expansión de los criterios y estándares anglosajones en la regulación de los mercados financieros [Nölke, 2011;9].

El cuadro 11 muestra que con $80 \%$ del valor agregado como excedente de explotación, y 14\% en salarios, lo convierte en la rama con mayor concentración del ingreso de Estados Unidos. La interrogante es si siempre fue así, o si esta

Cuadro 11. Estructura del PIB del complejo financiero bancario de Estados Unidos (porcentaje)

\begin{tabular}{lrrrrrrr}
\hline \multicolumn{1}{c}{$P$ PIB } & 2004 & 2005 & 2006 & 2007 & 2008 & 2009 & 2010 \\
\hline $\begin{array}{l}\text { Total bancos, valores, } \\
\text { seguros, fondos, bienes } \\
\text { ráces, alquileres }\end{array}$ & 100.0 & 100.0 & 100.0 & 100.0 & 100.0 & 100.0 & 100.0 \\
$\begin{array}{l}\text { y arrendamiento } \\
\text { financiero }\end{array}$ & & & & & & & \\
Excedente/PIB & 79.77 & 80.23 & 80.04 & 80.08 & 79.90 & 80.68 & 80.27 \\
Salarios/PIB & 14.99 & 14.79 & 14.91 & 14.85 & 14.81 & 13.87 & 14.18 \\
Impuestos/PIB & 5.24 & 4.98 & 5.06 & 5.07 & 5.29 & 5.45 & 5.56 \\
\hline
\end{tabular}

Elaboración propia. www.Bea.org 
estructura de valor agregado fue convertida en las décadas recientes. La hipótesis es que se transformó a partir de la década de los años ochenta y noventa, buscando oportunidades, eliminando restricciones y desregulando la actividad en mercados financieros y bancarios extranjeros.

El primer paso hacia la desregulación se dio en marzo de 1980 cuando

El 31 de marzo de 1980, el presidente Carter firmó la Ley de Desregulación de Instituciones de Depósito y de Control Monetario, la legislación federal más importante que se relaciona con la comunidad financiera desde 1930. La ley tiene nueve títulos que cubren una amplia gama de temas, incluyendo exigencias de reservas, acceso a, y un precio preferente de los servicios de la Reserva Federal, una reducción progresiva de la regulación Q y nuevos poderes para instituciones de ahorro. (http://www.bos.frb.org/about/pubs/deposito.pdf, Introducción, consultado 11 de mayo de 2013).

Entre 1980 y 1999 se produjo una concentración del poder político de un grupo de bancos, que logró hacer las modificaciones legales necesarias para convertirse en demasiado grandes para quebrar; es decir, un seguro de que pueden actuar sin tomar el riesgo en consideración, ya que siempre serán rescatados por el dinero de los contribuyentes. Su objetivo es la concentración del ingreso en el sector financiero. Esto es a lo que Ibarra y Tello [2012] se refieren como la revolución de los ricos. Y vendría a ser el resultado de la actuación del complejo bancario en su proceso de consolidación entre 1980 y 1999. Con este control político no dejan actuar fuera del complejo a quienes desean regular o morigerar su actuación. 
El cambio en la estructura bancaria de los años ochenta llevó a una creciente concentración de la actividad. Entre 1960 y 2005, por ejemplo, el número de bancos en Estados Unidos se redujo de 13000 a 6 500. Entre 2005 y 2012 la reducción adicional se ha dado por la quiebra de 457 bancos medianos y pequeños, y la fusión de los bancos mayores de inversión con los bancos comerciales muy grandes para quebrar, formando nuevos Bank Holding Companies que consolidan el proceso de concentración financiera. Según el National Information Center, de los 50 Bank Holding Companies al 30 de junio de 2012, los 10 mayores represen$\tan 73.8 \%$ de los activos totales de los primeros 50 , y son 34 veces más grandes que los 10 bancos menores del medio centenar señalado. En otras palabras, hay 10 bancos que en realidad constituyen el complejo financiero bancario y deciden y definen su modo de operación.

El aseguramiento de la influencia política en Estados Unidos se compra. Según el Center for Responsive Politics, de Washington D.C., los diez mayores contribuyentes a la campaña electoral provienen de la banca, y de estos, el agente que más dinero puso en la campaña electoral del 2011 y 2012 fue Goldman Sachs, seguida de Bain Capital, propiedad del candidato republicano a la Presidencia Mitt Romney. En octavo lugar está Bank of America y en noveno JP Morgan Chase.

Dentro del universo de actividades que aportan a la campaña, también es el complejo bancario el mayor contribuyente con $21.1 \%$ del total de recursos para la campaña presidencial 2011-2012, mientras el sector defensa ha perdido posiciones, convirtiéndose así este complejo en el de- 
Cuadro 12. Contribuyentes por empresa del complejo financiero bancario a la campaña electoral 2011-2012

\begin{tabular}{lc}
\hline \multicolumn{1}{c}{ Contribuyente } & Monto (en dólares) \\
\hline Goldman Sachs & 5448003 \\
Bain Capital & 4663378 \\
National Assn of Realtors & 4069474 \\
Clarium Capital Management & 3787200 \\
Crow Holdings & 3697600 \\
JW Childs Assoc & 2792700 \\
Friess Assoc & 2598889 \\
Bank of America & 2529637 \\
JP Morgan Chase \& Co & 2393832 \\
Citadel Investment Group & 2370075 \\
Renaissance Technologies & 2345650 \\
Blackstone Group & 2345303 \\
Elliott Assoc & 2331140 \\
Deloitte LLP & 2248049 \\
Morgan Stanley & 2246324 \\
Wells Fargo & 2052917 \\
New York Life Insurance & 2022876 \\
Euclidean Capital & 2022500 \\
Credit Union National Assn & 1938700 \\
Pricewaterhouse Coopers & 1933030 \\
\hline
\end{tabular}

Fuente http://www.opensecrets.org/industries/index.php 
terminante de la política nacional estadounidense, además del mayor empleador después del Gobierno. ${ }^{26}$

Así, por ejemplo, se dejaron de lado las recomendaciones del informe Stiglitz [2010] para reformar el sistema financiero y bancario internacional presentado en las Naciones Unidas en marzo de 2009 a favor de medidas bilaterales de Estados Unidos mediante la ley Dodd-Frank de 2010.

La formulación de políticas públicas de Estados Unidos debe ser explicada. La acción combinada del sector bancario sobre el gobierno -mediante los lobbies- desemboca en la representación de los intereses del sector bancario en el gobierno -por el nombramiento del secretario del Tesoro-. Este es el complejo bancario, para usar el feliz término de Eisenhower para referirse al complejo militar-industrial. Dado que el complejo financiero bancario es dueño de una parte del sistema de la banca central [FED] y que propone a los secretarios del Tesoro, tiene la capacidad para privatizar el proceso regulatorio. De esta manera, el Congreso aprueba leyes impulsadas desde la Casa Blanca y el Tesoro de manera disciplinada. Dado el papel líder del secretario del Tesoro como pivote del complejo bancario, este domina la agenda financiera y bancaria nacional, que a su vez se expande internacionalmente por el FMı. A partir del año 2008 también mediante el G20. ${ }^{27}$ Esta dinámica, acompañada de

${ }^{26}$ Disponible en http://www.opensecrets.org/industries/index.php Consulta: 08 febrero 2013.

${ }^{27}$ En la cumbre del G20 en noviembre del 2008 en Washington, se establecieron dos principios para guiar las reformas de los mercados financieros: una era potenciar regulaciones (nacionales) sólidas, y la otra reforzar la cooperación internacional para que las leyes (nacionales) sean más consistentes en todos los mercados. Cuatro años más tarde, esta 
las presiones británicas y europeas facilita la privatización de la gobernanza financiera estadounidense y global. También se podría afirmar que el peso de la actividad financiera es lo suficientemente grande como para incidir en la agenda global del G20. Hay la convicción creciente de que el multilateralismo es disfuncional y debe ser remplazado.

\section{EN SUMA}

Parece haber en marcha un proceso de desregulación financiera y bancaria que ha llevado a niveles de concentración de la actividad financiera debajo del paraguas bancario de Estados Unidos. Esto incide en la forma de operación del sector en todo el mundo por las influencias del fml y más recientemente del G20.

El sistema financiero, conocido por ser un sistema cerrado y relativamente regulado desde los años treinta, pasó a ser un complejo que incorpora actividades financieras, de bolsa, de seguros y de banca; que necesita del poder político para asegurar legislación a su favor; que tiene a un sector de la academia pensando sus argumentos, y que invierte en el Congreso estadounidense y en la campaña electoral con ese fin.

Tras la crisis, todo parece indicar que el complejo continúa operando y que la incorporación de lo académico con

visión se ha transformado en el intercambio de políticas desde una perspectiva transfronteriza y por eso la necesidad de las regulaciones del Comité de Basilea. 
lo político y lo gremial bancario ha ganado más peso, de manera que busca remplazar a la institucionalidad multilateral del FMI por una nueva administrada por este mediante la Secretaría del G20 y la agenda establecida por el B20, agrupación de empresas trasnacionales, muchas financieras, que asesoran al G20. Esto tiene repercusiones en todo el orbe, porque el complejo actúa de manera global por medio de sus sucursales y de sus inversiones en bancos fuera de su espacio nacional. 


\section{LA CRECIENTE CONCENTRACIÓN \\ DEL INGRESO EN EL MUNDO, 1970-2010}

INTRODUCCIÓN

Ante el estancamiento con inflación de la década de los años setenta y ochenta tempranos, las modificaciones de política económica que realizaron los gobiernos estadounidense con Ronald Reagan y británico con Margaret Thatcher, y los cambios teóricos dentro de las instituciones financieras internacionales -FMl y BM-formaron parte de un intento por superar mediante la acumulación financiera, el escenario estacionario postulado por los autores clásicos como Adam Smith, David Ricardo y Thomas Malthus, estimulando la concreción del proceso mercancía-dinero incrementado planteado por Marx por medio de un mecanismo de acumulación distinto de reinversión de los excedentes. Se introdujeron políticas de concentración acelerada del ingreso nacional y mundial.

En el decenio citado, los cambios en las relaciones económicas de los países de capitalismo avanzado se centraron primordialmente en torno a la caída de las tasas de ganancia industriales de naciones como Estados Unidos, Gran Bretaña, Francia y Alemania [Mandel, 1974]. En dicho contexto, el deterioro del patrón técnico fundamentado en el motor de combustión arraigado al patrón productivo fordista-tayloris- 
ta desempeñó un papel fundamental, ya que la productividad del trabajo creció a un ritmo decreciente, acompañado de una producción anual en descenso con respecto a las inversiones en el capital fijo [Duménil y Lévy, 2002].

El naciente patrón tecnológico centrado en la informática, desarrollado por las tecnologías de la información y comunicación, transformó el carácter de la actividad económica internacional, generando una incompatibilidad con el mecanismo de acumulación de capitales, basado en el paradigma keynesiano promotor del empleo mediante la inversión pública y el consumo de las clases medias por déficit fiscales crecientes.

Lo anterior llegó a un límite en 1971, y generó entre otras consecuencias, la flotación y posterior caída de la convertibilidad dólar-oro, que significó la ruptura institucional de los acuerdos internacionales de Bretton Woods emitidos en la etapa de la posguerra y los cambios mencionados. Por ello, las restructuraciones de la economía de Estados Unidos y los países integrantes de la Organización para la Cooperación y el Desarrollo Económico [OCDE] a finales de la década de los setenta y ochenta tempranos, se resumieron en un primer momento en políticas de austeridad monetaria y aumento de las tasas de interés, que impactaron de manera contundente en las economías latinoamericanas a partir de junio de 1981. En el ámbito internacional, se establecieron reorganizaciones paulatinas en las relaciones productivas, comerciales, institucionales e ideológicas que articulaban una nueva forma de desarrollar la economía y las relaciones sociales, ideológicas y culturales en conjunto a partir del discurso hayekiano del mercado. 
El proceso de financiarización emergió de manera gradual a partir de la década de los años ochenta, desplazando el papel central del sector productivo en las actividades de la economía. Esto promovió la consecución de altas utilidades por parte de la banca internacional y las empresas trasnacionales en mercados especulativos que traspasan las fronteras de las economías de capitalismo avanzado.

Sin embargo, la apertura y desregulación de las actividades financieras ha fomentado la volatilidad en los mercados cambiarios, de valores y de materias primas, con efectos sobre las economías nacionales, interconectadas por el proceso globalizador. Baste recordar la crisis japonesa de 1990 en adelante, las distorsiones de las economías mexicana, brasileña y argentina en el transcurso del decenio de los noventa, el derrumbe de los Tigres Asiáticos en 1997, y las recesiones de las economías estadounidense y europeas actuales, iniciadas a partir del año 2008 y 2010 respectivamente.

Uno de los resultados más visibles de dichos procesos económico-financieros a nivel global ha sido la concentración masiva de los ingresos [Palma, 2009]. En función de lo anterior, este capítulo propone examinar la manera en la que se han distribuido los ingresos internacionales a partir de la década de los años setenta.

Se parte de la hipótesis de que, posteriormente a la década de los setenta, la brecha entre los recursos monetarios internacionales ha ido en aumento, generando una tendencia sin precedente histórico. Para cumplir con el objetivo planteado se utiliza como indicador el Producto Interno Bruto per cápita calculado por el Banco Mundial 
en ppp. ${ }^{28}$ El procedimiento se llevó a cabo de la siguiente manera: se obtuvo la media no ponderada del ingreso por habitante de cada país durante las décadas analizadas. Del listado total, se extrajo la información de los cinco países de los extremos con respecto al periodo 2010-2011 (cuadro 13). Se calculó el ingreso promedio ponderado per cápita de ambos segmentos de países, dividiéndolos entre sí para mostrar la magnitud de la brecha (cuadro 14).

\section{LA CONCENTRACIÓN DEL INGRESO MUNDIAL}

Considerando la década de los ochenta, Mónaco resultó ser la economía con el ingreso más alto en el mundo, siendo constante su presencia durante los decenios siguientes. Sin embargo, es necesario considerar que aunque los altos niveles de ingresos de dicha economía provienen de la actividad turística, un factor importante que la coloca en los primeros peldaños del listado es su demografía. Hoy día, Mónaco es el segundo territorio con menor número de habitantes, con poco más de 30000 habitantes en promedio.

En segundo lugar, se ubican los Emiratos Árabes Unidos. La coyuntura de las crisis petroleras en el decenio anterior, que fomentaron el alza de los precios de los hidrocarburos, favorecieron a una nación rica en petróleo y gas natural

${ }^{28}$ El Producto Interno Bruto trabajado por el Banco Mundial representa la suma del valor agregado bruto de todos los productores residentes en la economía más impuestos a los productos, menos subsidio no incluidos en el valor de los productos. Lo anterior es dividido por la población a mitad del año, y ajustado por la paridad del poder de compra. 
que dejó atrás el Protectorado de Gran Bretaña en 1971. Los y las habitantes de dicho país árabe promediaron un ingreso anual de 32000 dólares. Para observar la magnitud de dicho ingreso, por ejemplo, hay que recordar que la economía hegemónica estadounidense pudo superar dicho monto en el decenio del dos mil, mientras que la economía japonesa promedió datos similares en la década de los años noventa del siglo pasado.

En dicho listado figura Liechtenstein, que representa un caso similar al de Mónaco. Aunque dicha economía cuenta con un sólido nivel industrial, sostenida además por el peso del sector financiero, esta población representa el cuarto país más pequeño del mundo, y cuenta actualmente con 34 000 habitantes en promedio. Qatar, el quinto país con más ingresos por habitante de la década, se benefició de la misma manera del contexto internacional al ser productor de combustibles fósiles. Por último, la creciente expansión del entorno financiero internacional impactó de manera positiva en la economía suiza, que promedió alrededor de 20000 dólares anuales per cápita.

Con respecto a las naciones económicamente más desfavorecidas, los y las habitantes de las naciones africanas de Malawi, Tanzania, Guinea-Bissau y Somalia, así como el territorio asiático de Nepal sobrevivieron en la década de los setenta con 167 dólares anuales per cápita en promedio. Para citar un ejemplo de la gravedad de la pobreza que se vive en la región africana veamos el caso de Ruanda. El ingreso de dicho país aumentó en 260\% los últimos 30 años. Una primera interpretación podría centrarse en el papel del crecimiento económico, sin embargo, dicha tasa avanzó a 
un modesto 1.2\% anual para el periodo 1970-1990.29 Un factor importante que potencializó que los datos se elevaran resulta el genocidio encabezado por el gobierno nacional cometido en 1994. Este acabó con la vida de 800000 personas, $11 \%$ de la población. ${ }^{30}$ Lo anterior generó que el ingreso per cápita del país presentara rendimientos significativos durante los dos decenios.

La década de los años noventa se caracterizó por presentar un periodo en que no solo continuó ampliándose la brecha entre los ingresos de los países analizados, sino que llegó al extremo de duplicar la relación con respecto a la década anterior. El monto de los países más pobres representados por el Congo, Etiopía, Burundi, Somalia y Liberia resultó 364 veces inferior al promedio generado por Mónaco, Liechtenstein, Suiza, Islas del Canal y Suiza.

En el transcurso de los 10 primeros años del siglo xxI, la relación entre ambos segmentos de países continúo con una tendencia estratosférica, llegando al límite de multiplicarse por cinco el presupuesto de los países ricos. Un caso que destaca por su dramatismo es el total de ingresos con los que sobrevive la población del Congo. En el transcurso de la década de dos mil, el ingreso promedio anual fluctuó en los 130 dólares, 40 dólares menos que lo destinado en la década de los años noventa, 200 dólares con respecto a la década de los ochenta y 280 dólares en relación con el decenio de los setenta. Dentro de las naciones con me-

29 Disponible en http://www.unicef.org/spanish/infobycountry/rwanda_statistics.html. Consulta: 06 de febrero de 2013.

30 Disponible en http://www.globalsecurity.org/military/world/war/ rwanda.htm. Consulta: 06 de febrero de 2013. 
Cuadro 13. Producto per cápita de los siete países con mayor y menor ingreso del mundo 1980-2011 (ppp, dólares constantes del 2005)

\begin{tabular}{|c|c|c|c|c|}
\hline \multicolumn{5}{|c|}{ Altos ingresos } \\
\hline País & 80 's & 90 's & 2000 's & $2010-2011$ \\
\hline Qatar & - & - & 67891.1 & 73892.5 \\
\hline Luxemburgo & 32027.0 & 48840.1 & 66961.5 & 68569.0 \\
\hline Singapur & 18775.1 & 31128.9 & 43347.6 & 52880.5 \\
\hline Noruega & 29278.8 & 37511.9 & 46657.9 & 46943.7 \\
\hline Kuwait & 27866.4 & 40885.2 & 44452.1 & 46778.9 \\
\hline Brunei & 59971.4 & 50104.6 & 48434.6 & 45607.0 \\
\hline Suiza & 30704.2 & 33645.9 & 37182.6 & 39238.7 \\
\hline \multicolumn{5}{|c|}{ Bajos ingresos } \\
\hline Sierra Leona & 774.8 & 567.4 & 618.6 & 755.4 \\
\hline República Central Africana & 936.8 & 779.8 & 703.6 & 710.3 \\
\hline Níger & 795.0 & 639.9 & 618.9 & 646.1 \\
\hline Burundi & 651.5 & 595.0 & 500.2 & 528.4 \\
\hline Eritrea & - & 625.5 & 584.6 & 503.1 \\
\hline Liberia & 1029.8 & 207.0 & 394.3 & 502.5 \\
\hline Rep. Dem. del Congo & 748.9 & 404.0 & 273.9 & 322.9 \\
\hline
\end{tabular}

* Esta lista de países se conforma de acuerdo con el promedio de 2005 a 2011 del Banco Mundial, el cual considera una muestra de 180 países. El producto está medido en valores de paridad de poder adquisitivo.

Elaboración de F. Martínez Cervantes, proyecto ॥EC OBELA del Banco Mundial. wDI Disponible en http://datos.bancomundial.org/indicador/NY.GDP. PCAP.CD Consulta: 10 de febrero de 2013. 
Cuadro 14. Promedio ponderado de países según su PIB per cápita y brecha del ingreso*

\begin{tabular}{lrrrr}
\hline & \multicolumn{1}{c}{80 's } & \multicolumn{1}{c}{90 's } & \multicolumn{1}{c}{ 2000's } & 2010-2011 \\
\hline $\begin{array}{l}\text { Países con alto ingreso } \\
\text { per cápita }\end{array}$ & 27769.8 & 34477.6 & 43704.4 & 48174.0 \\
$\begin{array}{l}\text { Países con bajo ingreso } \\
\text { per cápita }\end{array}$ & 728.9 & 481.1 & 394.4 & 438.5 \\
Brecha de ingreso & 38.1 & 71.7 & 110.8 & 109.9 \\
\hline
\end{tabular}

*Elaboración propia. Banco Mundial. Disponible en http://datos.bancomundial.org/indicador/NY.GDP.PCAP.CD Consulta: 10 de febrero de 2013.

nores recursos monetarios figuró Afganistán, mientras que Luxemburgo, las Bermudas y Noruega forman parte de las cinco potencias per cápita.

El cuadro 13 señala a las naciones con mayor y menor ingreso per cápita en el mundo para el periodo 2010-2011. Dentro de este listado se encuentran países como Qatar, Luxemburgo, Singapur, Noruega, Kuwait, Brunei y Suiza como las naciones con mayor riqueza. Del lado contrario se ubican Sierra Leona, República Centroafricana, Níger, Burundi, Eritrea, Liberia y el Congo. De este grupo de países se analiza su desenvolvimiento per cápita en los distintos decenios, partiendo de los años ochenta.

El cuadro 14 destaca el promedio por década de ambos grupos de países, mostrando la magnitud de su diferencial. Lo que podemos constatar es que prevalece una tendencia creciente hacia la concentración de los ingresos. El diferencial pasó de 38\% durante el decenio de los ochenta, para dar un salto casi al doble en relación con los noventa. La brecha se hizo más aguda en la primera década del nuevo 
milenio, al mostrar una relación de 110\%, es decir, el triple con respecto a la década citada. Considerando el periodo 2010-11, el diferencial de ambos grupos de países mantiene $300 \%$ de diferencia.

\section{LA CONCENTRACIÓN DEL INGRESO COMO FRUTO DE LOS AJUSTES}

La creciente brecha entre los ingresos por habitante en las distintas coordenadas del mundo, potenciadas a partir de la década de los setenta, presenta una correspondencia sistémica con las modificaciones político-institucionaleseconómicas-ideológicas-sociales, fundamentadas por el paradigma neoliberal institucionalizado por el Consenso de Washington [Williamson, 1990]. Dicho entorno caracterizado en la esfera económica principalmente por desplegar mecanismos de desregulación financiera, privatización de empresas paraestatales y apertura comercial, ha vulnerado el crecimiento económico -y por ende el desarrollode los países denominados por el presidente de Estados Unidos Harry Truman en 1949 como "subdesarrollados".

Es este contexto geopolítico es necesario hacer visible el papel que tienen los países hegemónicos de capitalismo avanzado y las instituciones financieras internacionales que conforman el establishment de la política internacional. Como parte de esta configuración inherente del sistemamundo prevalecen voces como la del economista brasileño Celso Furtado que considera que el fmı representa el brazo extendido del Tesoro estadounidense. 
Dicha institución ha penetrado e impuesto ajustes estabilizadores en los países periféricos principalmente -véase actualmente los países europeos- que se encuentran sumidos en crisis financieras y productivas que han venido luego acompañadas por reformas estructurales del Banco Mundial, cuyo objetivo ha sido la concentración del ingreso mundial. El argumento oficial es que las recomendaciones emitidas por dichas instituciones en materia de políticas económicas transitan por un camino que estimula el crecimiento económico. No obstante, lo que se puede apreciar en muchos casos en el mundo -sea las economías latinoamericanas, africanas, asiáticas o ahora europeas- es que la promoción de políticas de libre mercado ha debilitado la soberanía en muchos rubros de las economías dependientes, a cambio de la penetración masiva de capitales extranjeros en las mismas. Es decir, vivimos un momento en que las economías de capitalismo dependiente se desarticulan internamente para enlazarse globalmente.

Sin duda, Bello y Ambrose [2006] consideran que las instrucciones que ha emitido el Fondo han generado una pobreza más profunda, indicadores en descenso en materia de salud, educación y vivienda, así como economías subdesarrolladas dependientes del suministro de materias primas y mano de obra barata. Se puede agregar que las reformas del Bм han congelado dicha situación.

Históricamente, los países de capitalismo avanzado difícilmente llegaron a tales escenarios de desarrollo económico capitalista sin una acción estatal decisiva. Por ejemplo, en el siglo xvIII el gobierno de Gran Bretaña empleó políticas de protección a las importaciones y de fomento a las exportaciones y a las industrias nacientes. Por otro lado, las políticas 
económicas puestas en práctica por los gobiernos de Estados Unidos generaron que dicha nación fuera la economía más proteccionista del mundo desde mediados del siglo xIx hasta la segunda guerra mundial [Chang y Grabel, 2006].

Por ello, Chang [2004] considera que los países ricos han "pateado la escalera" del desarrollo a los países del Tercer Mundo, ya que desde la década de los cincuenta del siglo pasado el establishment internacional ha obligado a los países periféricos a alcanzar estándares y adoptar políticas que detienen su progreso económico. En palabras de Gunder Frank [1967] los países en vías de desarrollo -teorizando en el caso latinoamericano- únicamente han "desarrollado el subdesarrollo".

Lo que se ha observado es que aquellas economías que han decidido desligarse de las recomendaciones emitidas por el fmı del pago de sus deudas, muestran indicadores de crecimiento por encima de las economías atadas a dicha institución. Véase el caso de las economías asiáticas luego de su caída en 1997-1998, Argentina y Brasil en la década de los años dos mil, así como el actual caso de la economía de Islandia en la región europea, que ha optado por una vía distinta a la de la austeridad propuesta por la Troika, consorcio conformado por la Unión Europea, el Banco Central Europeo y el fmı para asesorar las políticas económicas de Europa. La interrogante que se abre es, si el fml fue diseñado para garantizar la estabilidad de las balanzas de pagos, ¿qué hace Europa que no tiene un problema de balanza de pagos? ¿Sigue como brazo de política exterior de Estados Unidos?

Las consecuencias sociales neoliberales han llegado al límite de consolidar territorios hiperdegradados, producto de los ajustes estructurales y la estabilidad macroeconómi- 
ca. La creciente urbanización en los países no desarrollados ha dejado como legado a las regiones con menores ingresos una propensión a desconectar de manera radical el empleo formal, lo cual ha derivado en la consolidación de ciudades-miseria [Davids, 2004]. De la misma manera, la contracción económica ha recreado expresiones de xenofobia, intolerancia a la diversidad sexual y represalias contra los trabajadores migrantes que van en aumento, generando un entorno de violencia y militarización.

Por otra parte, prevalecen nociones teóricas que han sido poco cuestionadas, las cuales dan sustento a las construcciones económicas. Por ejemplo, uno de los indicadores más destacados para medir el "bienestar" por país es el Producto Interno Bruto per cápita. Este índice resulta una estimación que técnicamente calcula el total de ingresos derivado de la producción de bienes y servicios anual entre el total de la población; sin embargo, es necesario hacer notar que no existen vínculos que nos permitan considerar que los crecimientos económicos nacionales medidos por los aumentos cuantitativos de las producción se traduzcan en mejores condiciones de vida de la población, como la distribución de la riqueza.

Considerando la lógica sistémica de dicha etapa histórico-económica de desregulación y apertura financiera, se observa que las ganancias fomentadas en los mercados financiarizados no tienen vínculo con las actividades productivas. Lo anterior impacta de manera directa sobre el empleo y a su vez sobre el consumo, derivando en una disminución en la calidad de vida de la población, al no satisfacer servicios básicos como la salud, vivienda, educación, alimentación, etc. En contraparte, como se demuestra en 
el transcurso del capítulo, el ingreso mundial se ha concentrado en las actividades especulativas.

Otro punto que es necesario considerar es el factor demográfico. Aunque una política de control natal puede resultar funcional para las expectativas de crecimiento en las economías de mercado, los problemas de pobreza monetaria en los países de capitalismo dependiente resultan de una condición estructural que no es atendida por las llamadas reformas estructurales del Banco Mundial. Estas, han generado una crisis alimentaria derivada primordialmente del alza de los precios de los granos básicos manipulados, por ejemplo, mediante los acaparamientos masivos, la transformación de cereales en combustibles como el caso del maíz, ahora producido para convertirlo en etanol; y la compra creciente de tierras fértiles por parte de bancos, empresas y fondos de inversión [Guillot, 2012], y promovido la agudización de la distancia entre ingresos.

Siguiendo los postulados de Prebisch [1996], el crecimiento económico tiende a producir en el largo plazo cambios profundos en la estructura económica, generando distorsiones principalmente en el mercado de trabajo, y per se en las estructuras macroeconómicas de los países periféricos, al distribuir de manera desigual los frutos del progreso técnico.

Uno de los múltiples resultados de dichos procesos de reformas ha sido que la desigualdad de los ingresos en el mundo se ha disparado a niveles insuperables. En el año 2010 llegó al paroxismo la diferencia entre los ingresos en 229 veces entre el país más rico del mundo por habitante, Qatar, y el más pobre, la República Democrática del Congo. Comparado veinte años atrás, en 1990, que era de 42 
veces, entre Estados Unidos y Guinea, que eran el más rico y el más pobre respectivamente. ${ }^{31}$ En términos absolutos, tomando los extremos, la desigualdad global ha crecido cinco veces en los veinte años de las reformas.

Aun cuando han emergido naciones semiperiféricas que han consolidado procesos de industrialización, demandando mayores volúmenes de materias primas y energía, han financiado préstamos a las naciones desarrolladas mediante la acumulación de mayores volúmenes de reservas internacionales. Bajo los lineamientos del FMl, estos países han cambiado deuda pública externa por deuda interna, esterilizando las reservas y empleando la acumulación de divisas y los influjos de capital para mantener las metas de inflación [Lara Cortés, 2009].

Por otro lado, una idea que no hay que dejar pasar de largo es el hecho de que territorios que son paraísos fiscales y financieros, como las Islas Bermudas e Islas del Canal, figuren entre los países con mayores ingresos por habitante. Con baja densidad poblacional, dichos territorios son paraísos fiscales y financieros que atraen grandes capitales e inversiones especulativas ya sea de procedencia lícita o no.

\section{EN SUMA}

La concentración de la actividad financiera generada por la política económica introducida en Estados Unidos con

${ }^{31}$ Se ha utilizado la base de datos de varios años de unDP del Informe para el Desarrollo Humano para medir los países extremos en 1990 y 2010. 
Ronald Reagan y en Gran Bretaña con Margaret Thatcher, acompañado de los cambios teóricos en el mundo académico y en el fml llevaron a una creciente concentración del ingreso, primero en Estados Unidos y Gran Bretaña, y luego en el mundo. La aplicación general de las políticas ha llevado a una creciente desigualdad del ingreso mundial entre los años 1990 y 2010 en el que la distancia promedio entre los países más ricos y más pobres se ha triplicado y en los extremos se ha quintuplicado.

La financiarización es el producto del estancamiento productivo de los años setenta, cuyo origen es el agotamiento de la generación tecnológica basada en el petróleo. La nueva base de tecnologías basadas en la información ha conllevado mayor financiarización, porque existe la tecnología para hacerla global. Con instrumentos y políticas que facilitan esto, una mayor desigualdad del ingreso es el resultado natural. 


\section{EPÍLOGO32}

En agosto de 2007 se inició en Estados Unidos la crisis llamada "de las hipotecas de mala calidad" que reventó finalmente en septiembre de 2008, con la quiebra de Lehman Brothers y el crack de las bolsas de valores. La naturaleza de la crisis ha estado en cuestión y hay distintos puntos de vista sobre su complejidad. La triple crisis es una entrada, y las crisis energética, alimentaria y económica van de la mano. Otro enfoque es la crisis de larga duración, como propone Arturo Guillen. Otro más, que se trata de una crisis financiera que ya pasó (2007-2009) y entonces en Europa estamos ante otra crisis (véase gráfica 7). Esta es una lectura muy anglosajona y metabolizada por la ocDE. Otras lecturas de mayor alcance permiten avizorar que se trata de un cambio de tiempos. En este sentido, la postura de una crisis civilizatoria propuesta por Aníbal Quijano y Boaventura dos Santos está más cerca a la realidad observada que las anteriores, más orientadas a que se trata de una crisis económica.

La falta de crecimiento en las economías maduras, imbuidas en sobreendeudamiento y alto desempleo, abre la interrogante sobre el capitalismo maduro. ¿Es ese el fin

32 Estas conclusiones fueron publicadas en ALAlnet.org, América en movimiento, de abril, 2013. 
utópico de lo que estamos haciendo todos en el mundo en desarrollo? Las consecuencias expuestas sobre el planeta plantean como horizonte la destrucción de la vida. El informe de la European Environmental Agency de noviembre del 2012 advierte que el aumento de la temperatura del globo será de alrededor de 3.6 a 40 Celsius entre el 2010 y el 2100. Reconoce al mismo tiempo que esto se da tras el aumento de $1.3^{\circ}$ Celsius desde la Revolución Industrial hasta la primera década del siglo xxı. Las consecuencias se pueden apreciar en la tormenta que inundó y congeló Manhattan en octubre del 2012, así como en el aumento de los desastres atmosféricos sufridos alrededor del mundo en la última década. La inviabilidad de la lógica del progreso como transformación de la naturaleza por el ser humano se ha hecho patente. Más que transformado, el ser humano ha destruido la naturaleza.

El refugio para las crisis siempre fue la creencia, pero esta vez tenemos una crisis religiosa, en especial en los continentes americano y europeo. Jan de Vos [2013] se refiere a la crisis en la Iglesia católica como una crisis cismática y abre la interrogante sobre la capacidad de regeneración que tiene para recuperarse del cisma en el que está inmersa. La Iglesia, dice Vos, está cada día más alejada de su feligresía. Los problemas en torno a esto los plantea Vega Centeno lúcidamente al sugerir que en América Latina lo que se comienza a observar es una pluralidad de creencias.

Por otra parte, la marcha económica desde hace tres décadas está orientada a las exportaciones mediante un salario bajo. El objeto de la política es la concentración 
Grafica 7. Crecimiento trimestral del pIB Eurozona,

1999- $3^{\text {er }}$ trimestre 2012. Cálculos del año 2012

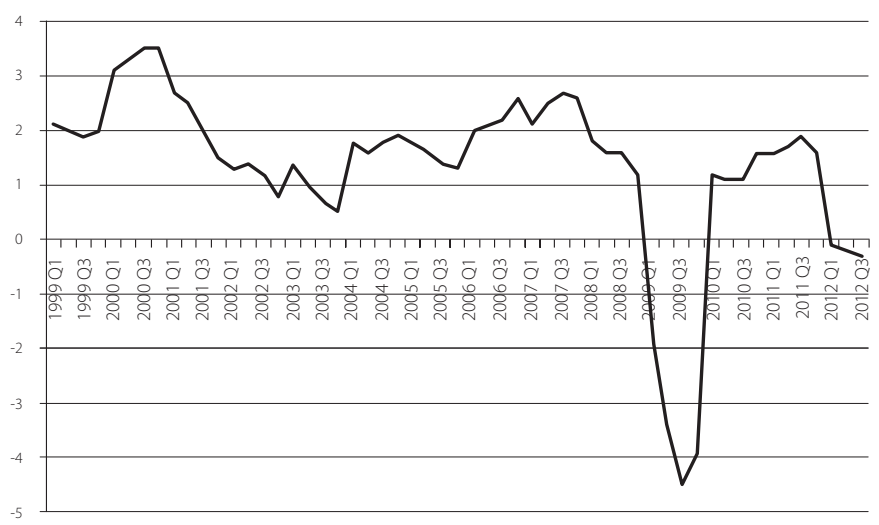

BCE. Disponible en: http://www.ecb.int/stats/prices/indic/forecast/html/ table_hist_rgdp.en.html. [Consulta: 1 de diciembre de 2012]. Elaboración propia.

del ingreso y lo ha logrado. Nunca en la historia ha estado el ingreso mundial más concentrado, y nunca en la historia ha habido tal distancia entre los países pobres y los ricos. En el mundo colonial había un cierto equilibrio de riqueza. El fin de colonizar era trasladar riquezas de un lado al otro del mundo. En el mundo neocolonial, el objeto es empobrecer un lado del mundo que crece, para enriquecer al otro que no crece. El mundo y sus riquezas se subordinan a lo que requieren las grandes potencias. Excepto que esta vez entraron a la lista de grandes potencias otros países que están transformando la estructura global de poder. 
El mercado figura como la nueva verdad revelada de nuestra época. El mercado se ha asumido en el imaginario colectivo como un ente omnipresente y perfecto. Este dogma se ha cobijado y reafirmado por las aportaciones teóricas neoliberales en el campo económico, la postura neoconservadora en el ámbito político, y las teorizaciones de la filosofía política que en general deshumanizan a los seres humanos, es decir, hemos sido despojados de nuestras características de sexo, género, clase, raza, etnia, etc., en un contexto en el que la colectividad no tiene cabida.

Así, las aportaciones teóricas expuestas por Michel Foucault resultan una aportación significativa, cuya valía radica en el intento de descifrar las relaciones de producción y de significación en la que están inmersas nuestras sociedades de manera compleja. Lejos del carácter institucional de estas relaciones a la manera de Weber, Foucault hace hincapié en el papel de nuestras conciencias. Tales subjetividades manifestadas en el sentido común son capaces de transformar las ideas para someter, dentro de un contexto económico-político histórico definido.

Por tanto, el fascismo y el estalinismo resultan dos formas patológicas de poder dentro de contextos muy precisos, articuladas a partir de las ideas y los procedimientos de nuestra racionalidad política. De esa misma manera, hoy día el mercado ha sometido la razón y la política con el soporte político neoconservador, más próximo al fascismo que al estalinismo, pero lejos de los espacios democráticos en construcción a partir del siglo xvII. Todo lo que se aleja de esta 
interacción se considera peligroso, como se ha manifestado desde diferentes trincheras oficiales hacia los gobiernos de Venezuela, Ecuador, Bolivia por citar algunos ejemplos

Al mismo tiempo, los colapsos bancarios rescatados por el Estado pusieron de relieve el doble discurso. "Muy grandes para quebrar" fue como se denominó a lo que antes llamábamos monopolios y "coordinación fiscal" se bautizó a lo que antes conocíamos como intereses grupales. El asalto del Estado por el complejo financiero bancario desnaturalizó el discurso del mercado en Estados Unidos. Salvo el poder, todo es ilusión, decía Mao, y dicen los banqueros en Estados Unidos que han llegado para quedarse en el Departamento del Tesoro, donde rotan de tiempo en tiempo, dentro de una puerta giratoria criminal, insuflada de intereses en conflicto. El mercado sí, pero con el Estado bajo control por las dudas para trasladar el ahorro que ellos necesitan. Pero solo para los monopolios del capital financiero bancario. El resto del sector financiero que se enfrente a las leyes del mercado. De este modo, 1500 bancos han quebrado entre 2008 y diciembre del 2012, pero los monopolios financieros han crecido: JP Morgan compró a Chase; Citibank compró el Bank of America, que había comprado a Merril Lynch, etc. Por ejemplo, Robert Rubin, último secretario del Tesoro en la etapa de la desregulación iniciada en 1980, que benefició a Citibank con una ley en 1998, recibió de Citibank 126 millones de dólares desde que dejó el cargo. Esto, en la ley de Estados Unidos, no es ni corrupción ni delito. La consecuencia para ellos del asalto al poder, por ejemplo, es que la crisis iniciada en el 2007, que contrajo el 
PIB de Estados Unidos, tuvo al mismo tiempo 1\% de crecimiento del sector financiero de aquel país en el 2009.

La gobernanza global antes centrada alrededor del FMI, el Banco Mundial y el multilateralismo público, organizado por Estados Unidos tras la segunda guerra, ha perdido fuerza. La crisis desde el 2008 ha mostrado que los Estados no sirven para gran cosa, salvo trasladar recursos al mercado financiero, y que solo el G20 tiene la solución. El G20 reúne a los Países Ricos Altamente Endeudados [PRAE] comenzando por Estados Unidos, Gran Bretaña, algunos europeos y Japón, con los acreedores más grandes del mundo desde China hasta Arabia Saudita. Así, los responsables de la crisis económica y financiera liderada por el mercado, son quienes hoy intentan imponer las nuevas reglas financieras y económicas en el G20 por medio del B20 y del T20, siendo el B20 un grupo de empresas, y el T20 un grupo de think tanks que le colocan la agenda al G20.

¿Es preferible un fmı reformado y democratizado, que dé cuenta a los nuevos poderes, con una nueva teoría económica que legitime una gobernanza privada que no tendría manera de rendir cuentas sino a sus socios? ¿O, la regionalización puede ayudar? La regionalización tiene la ventaja de acercar a las instituciones a sus Estados clientes y de responder de manera directa a las necesidades de estos. La idea europea de regionalización tuvo también un aspecto de agregación de poder de negociación, en el marco de la Guerra Fría. En América Latina, tiene el sabor de agregación de poder frente a Estados Unidos, que como vemos aún ahora, sigue interviniendo en la vida interna de los países 
para favorecer sus intereses, como si la Guerra Fría perviviera. Los gobiernos que desisten del discurso dogmático en América Latina han buscado la integración y han sido cuestionados por los que mantienen el discurso dogmáti$\mathrm{co}$, que tuvieron a uno de sus mejores expositores en Hugo Chávez. Este enfrentamiento ideológico económico tiene su correlato político, sin embargo, en los ejes políticos del hemisferio: Washington y Brasilia.

\section{POBLACIÓN, EMPLEO Y PRODUCTIVIDAD}

La esperanza de vida ha crecido en el mundo en las dos últimas décadas de manera muy visible. Quizá con la excepción de los países de la ex Unión Soviética que vieron una reducción significativa de su esperanza de vida en la década de los noventa; se puede apreciar que hay más personas trabajando por más años de vida útil. De manera simultánea, la revolución feminista incorporó a las mujeres en el mercado de trabajo. No obstante, tales procesos chocan con factores sistémicos, cuya incapacidad radica en la imposibilidad de la economía neoliberal de absorber las necesidades crecientes de empleo. En este entendido, Carlos Welti muestra cómo en Asia y América Latina principalmente, lo anterior ha tenido graves consecuencias en términos de desempleo juvenil y disminución del nivel salarial. Estos mecanismos también han tenido un impacto en términos ambientales en relación con el uso creciente de fertilizantes contaminantes y de basura tecnológica, con las consecuencias de ello en los flujos de agua. 
El envés de la crisis financiera de Estados Unidos y Europa es que esta parece haberse convertido en una "bendición" para América Latina, que recibe flujos crecientes de capital de corto plazo. Lo que está impactando es la diferencial de tasa de interés, con efectos sobre tipos de cambio y reservas internacionales. ¿Qué perspectivas se abren para América Latina en este panorama y cómo se pueden evitar? Sumergidos tanto dogmáticos como apóstatas en la crisis que tiene como efecto que las tasas de interés en Estados Unidos, Gran Bretaña, Europa y Japón sean negativas en términos reales, es decir, netas de inflación, ambos grupos de países están inundados de capitales de corto plazo y reflejan por tanto auges en los precios de sus bolsas de valores, sus tipos de cambio y sus mercados de bienes raíces. Las excepciones pueden ser Argentina seguida de Venezuela y quizás Ecuador.

A mayor crisis, menor capacidad de préstamos dentro de Estados Unidos, Gran Bretaña, Europa y Japón, y más necesidad de recurrir a mercados nuevos dinámicos. Al mismo tiempo, mientras más bajas las tasas de interés más se inyectan capitales a instrumentos de renta variable y más altos los índices de las bolsas de valores, inclusive en las economías críticas. De esta manera, se explica que los índices de Bolsa de Nueva York estén por encima de 2007, año del inicio de la crisis, a pesar de que su PIB casi no crece desde el 2009 y la perspectiva recesiva es fuerte. Eso es lo que se denomina como burbuja en términos financieros, debido a que no tiene detrás sustento real. Es puro efecto monetario producto otra vez de las políticas de la Reserva Federal, como lo fue en 2004 al 2007. La Unión Europa sigue el mismo curso, acom- 
pañada de Gran Bretaña y de Japón en lo que en términos cambiarios es percibido como una guerra de divisas.

El problema de la crisis yace en que la productividad de las economías líderes crece a una tasa baja, el consumo a una tasa alta, y el crédito para el consumo a una tasa aún más alta. Esto se dilató al punto de que las importaciones derivadas del alto consumo se hicieron inmanejables. Al perderse empleos, este esquema se revierte, se contrae el consumo, se contrae el crédito de consumo y en algún momento se inicia la recuperación de la productividad. Sin embargo, las políticas que se vienen aplicando tienen que ver con la reducción del empleo pero no con elevar la productividad, que busca mejorar por tipos de cambio-competitividad.

La combinación de bajas salariales, como factor esencial de la economía, aunado al crecimiento de consumo vía crédito, tiene efectos sobre la calidad de vida de la población. El empleo se ha vuelto más precario y los derechos sociales se han ido perdiendo a favor de la concentración del ingreso, objetivo central de la política. Cuando esa población protesta por la pérdida de empleo es percibida como una amenaza terrorista. Sin duda de eso se trata la transformación de las leyes contra la protesta social en leyes antiterroristas. Desde Chile hasta Estados Unidos la protesta social está catalogada como terrorista, el trato del detenido o detenida, por tanto, es el de no-ciudadano. La persona no tiene derechos cuando es detenida por terrorismo, siendo que en realidad lleva a cabo una protesta salarial, de empleo o de calidad de vida. El trato a quienes protestaban en Madrid, Nueva York y otras capitales en la ya disuelta 
campaña de Occupy Wall Street tenía esa dirección. El trato en Europa sigue siendo de ese modo. En este sentido, Saskia Sassen [2013] afirma que la democracia como la hemos conocido está debilitada, en particular en Estados Unidos.

Lo que enfrentamos es una degradación profunda del Estado liberal. Las matanzas por drones ${ }^{33}$ y el encarcelamiento ilegal están a un extremo de aquel espectro de degradación, y el asalto del poder, destrucción económica y arbitrariedad del sector financiero están al otro extremo.

Susan George acaba de publicar El informe Lugano // en el que argumenta que el sector financiero ha acordado que lo relevante no es la democracia, sino la rentabilidad, y que se debe hacer todo para garantizarla. Esta es básicamente la idea de Sassen y es la que se encuentra detrás del dogma económico. Baste recordar que este dogma se introdujo en el mundo en Chile, de la mano de Pinochet en 1974, con el inolvidable soporte del dúo Milton Friedman/Henry Kissinger y el auspicio financiero de la ITT.

\section{HACIA LA MILITARIZACIÓN DEL CONTROL SOCIAL}

La aplicación de la política del FED Ilamada Quick Easing consiste en inyectar liquidez comprando bonos del tesoro

33 Un drone es un equipo aéreo de guerra manejado a larga distancia por control remoto. Para más información véase http://dronewarsuk. wordpress.com/aboutdrone/ 
a los bancos de inversión que los tienen. Esto lo hacen todos los bancos centrales de los PRAE. Esa liquidez es luego usada por los bancos de inversión para invertir tanto en sus propias bolsas como en el exterior. Como los commodities se han titulizado, vale decir, tienen títulos valor con mercado propio, entonces los inversionistas compran cobre, títulos valor que respaldan cierta cantidad de cobre físico. La manipulación de estos títulos valor empuja los precios de las materias primas por encima de su nivel real de precios determinada por oferta y demanda física. Desde el año 2008 es evidente cómo los precios de las materias primas son determinados básicamente en el mercado de títulos valor. El efecto es un crecimiento muy fuerte en las economías lideradas por las exportaciones primarias de África y América Latina. Con altas tasas de crecimiento, los países dogmáticos no están dispuestos a escuchar a los apóstatas, que también crecen mucho, en la necesidad de crecer de otro modo, o de integrarse de otro modo al mundo, privilegiando el mercado de bienes industriales. Los países dogmáticos están cerrando filas mediante tratados y acuerdos con Estados Unidos para asegurar que el dogma sea siempre respetado. El más reciente, es el Tratado Trans-Pacífico TTP que aparentemente le da a las corporaciones más derechos, de manera análoga al Acuerdo Multilateral de Inversiones -AmI- que fuera suspendido en 1999 en Seattle, tras las protestas sociales.

El control social militarizado parece ser el nuevo rasgo de la crisis tanto en los PRAE como en el resto del mundo. El funcionamiento del complejo financiero bancario extendido en gran parte del mundo está en proceso de generali- 
zarse, articulándose de esta manera tanto la gran prensa como los intereses de esa gran banca, que al final son 30 instituciones y están representadas en el G20 y lo guían. No hay ninguna evidencia que algo esté impidiendo que lo financiero siga funcionando de la misma manera que antes de la crisis. La incapacidad de aprobar leyes regulatorias en Estados Unidos y la salida de Barney Frank del Senado dejan ver el peso que tienen. La presencia de allegados del Complejo Financiero Bancario en el Securities and Exchange Commission de Estados Unidos y el Tesoro de dicho país, así como la de banqueros de inversión en casi todos los gobiernos de Europa habla del asalto al poder también allá. El contrapoder, con la capacidad de cuestionar el dogma y el orden establecido crece en países de América Latina, sin embargo peligra. Las amenazas sobre Argentina, Venezuela, Bolivia, Ecuador, etc., van en esta dirección.

En términos de teoría económica, lo que se puede apreciar es que el dogma orientado a la concentración del ingreso también viene ganando posiciones en Europa. El FMI parece haber perdido peso allí frente a la Comisión Europea, que sirve de portavoz de esta postura. El problema de la concentración del ingreso, aunado al del sobre consumo y a la sobre acumulación siguen en el centro de la crisis. No han sido resueltos. Por el momento, la crisis "global" está dividida en dos, una parte se encuentra en IOS PRAE, en los que es evidente el deterioro continuo, y la otra en que los capitales de corto plazo fluyen y se siente el impacto de las alzas de los precios de las materias primas por las razones explicadas. Sin duda, la crisis se va a generalizar cuando los precios bajen por efecto de ajustes de tasas de interés o 
se reactiven loS PRAE. Esto último no resulta probable en un futuro previsible. En ningún caso, una reactivación basada en la tecnología, a su vez movida por la energía fósil es la solución, porque precipitará un desenlace indeseable. La interrogante es si existe otro modo de entender la economía que sea viable y si diseños como El Buen Vivir pueden tener proyección regional.

\section{A MANERA DE CIERRE}

Un punto que es necesario discutir es la noción de crecimiento económico como palanca de bienestar social. Después de la posguerra, las teorías del desarrollo plantearon la necesidad de estudiar las estructuras económicas a mediano y largo plazos de aquellos países que presentaban bajos niveles productivos, escaso empleo de tecnologías, desigual inserción en el comercio internacional, entre otros rubros.

La necesidad de alcanzar el desarrollo como camino para superar las sociedades tradicionales, en tanto comunidades ligadas a las relaciones sociales, políticas y económicas feudales, se apoyaban en el crecimiento económico como primera condición para superar tales limitaciones estructurales. Teóricamente, aportaciones como la de W.W. Rostow asentaron la idea generalizada de que los países subdesarrollados tendrían que transitar por diversas etapas para alcanzar el desarrollo, entendido como la reproducción económica y política de los países hegemónicos. 
De manera paralela, la vertiente latinoamericana de la década de los cincuenta auspiciada principalmente por Raúl Prebisch apostaba a la industrialización en su versión de sustitución de importaciones para alcanzar dicho escenario. Sin embargo, se han decantado una serie de problemas ambientales que cuestionan en la actualidad el supuesto progreso y bienestar social medido por los aumentos cuantitativos en la producción.

En este contexto, son cada vez más las opiniones que consideran urgente proponer otros criterios de apropiación de los recursos naturales que permitan asumir relaciones productivas que se alejen de los vínculos fomentados por el mercado, los cuales han generado como consecuencia una destrucción ambiental nunca antes imaginada.

No obstante, las estrategias geopolíticas que caracterizan hoy día a las naciones de capitalismo maduro en decadencia y a las economías emergentes apuestan por seguir con el mismo patrón energético de combustibles fósiles que promueve un mercado especulativo con ganancias en aumento. Los países más neoliberales como Chile, Perú y Colombia, enfatizan su papel primario de exportadores. Incluso posturas políticas progresistas de izquierda, por ejemplo los gobiernos de Venezuela, Bolivia y Ecuador en América Latina, insisten en la reproducción de parámetros extractivistas como parte del auge del mercado de los commodities, con la idea de emplear tales recursos para la disminución paulatina de las necesidades básicas de la población.

Una de las múltiples propuestas emitidas desde diferentes trincheras teóricas es la revaloración de los distintos conocimientos, saberes y cosmovisiones reproducidos a lo largo y ancho del mundo, que constituyen formas distintas 
de producción y de relaciones sociales. Es necesario enfatizar en la postura de Santos [2009] que considera que las experiencias sociales en todo el mundo son mucho más amplias y variadas que las validadas por la tradición científica y filosófica occidental.

En los países y en las mentalidades occidentalizadas principalmente se han desplegado procesos que favorecen la expansión del capitalismo, al reducir la multiplicidad de los mundos al mundo territorial propio de la geopolítica de las relaciones mediadas por los capitales y la multiplicidad de los tiempos al tiempo lineal. Para combatir este desperdicio no basta con proponer otro tipo de ciencia, se necesita partir de otro tipo de racionalidad que supere el ocultamiento y descrédito de los movimientos emergentes.

Parafraseando a Ana Esther Ceceña [2012], en la geopolítica imperante se ponen límites al capital pero no al capitalismo. A lo que muchas personas y movimientos sociales en resistencia alrededor del mundo aspiran es a construir opciones posdesarrollistas, en un proceso de larga duración que imagina trascender las organizaciones económicas, políticas y sociales inherentes al proyecto civilizatorio de la modernidad.

De lo que se trata es de no limitarse a una propuesta de desarrollo alternativo que plantee solo la estatización de los recursos naturales sin cuestionar la forma de extracción. Esto no quiere decir que se desestime la valía de estas luchas. La apuesta posdesarrollista aspira a ir más allá de promover alternativas a la visión del desarrollo que nos permitan encontrar una salida a la crisis de carácter complejo que estamos viviendo, dejando a un lado, entre muchos otros procesos, la depredación de la naturaleza como patrón de crecimiento. 
Para ello, se requiere mirar hacia horizontes más allá de lo existente, formulando propuestas suficientemente utópicas para desafiar el status quo imperante y necesariamente reales para no ser descartadas por su inaplicabilidad. Por tanto, la reproducción de una economía alternativa implica entonces una sociedad alternativa y viceversa [Santos y Rodríguez, 2012]. 


\section{REFERENCIAS}

Aguayo, Francisco (2012). "Climate change mitigation and institutions for sustainable development", en Ugarteche, O. y P. Dembinski (comp.) Más allá de Bretton Woods: la economía trasnacional en busca de nuevas instituciones, Saarbrücken, Alemania, Editorial Académica Española, pp. 320-339.

Alto Comisionado de las Naciones Unidas para los Refugiados (ACNUR) (2012). Mediterranean takes record as most deadly stretch of water for refugees and migrants in 2011. Disponible en http:// www.unhcr.org/4f27e01f9.html [Consulta: 30 de noviembre de 2012].

Banco Central Europeo (BCE) (2011). ECB announces measures to support bank lending and money market activity. Disponible en http://www.ecb.int/press/pr/ date/2011/html/pr111208_1.en.html [Consulta: 30 de noviembre de 2012].

(2012). The euro area bank lending survey: January 2012.

Disponible en http://www.ecb.int/stats/pdf/blssurvey_201201.pdf [Consulta: 30 de noviembre de 2012].

Bank of International Settlements (2011), "Basel III: A global regulatory framework for more resilient banks and banking system", Basel Committee on Banking Supervision, http://www.bis.org/publ/bcbs189.pdf. [Consulta: 09 de mayo de 2013). 
Bello, Walden y Ambrose, Soren (2006). Retirar el soporte vital al FMI. Disponible en http://www.rebelion.org/noticia. php?id=32450 [Consulta: 30 de noviembre de 2012].

Betto, Frei (2012). “El nuevo fetiche”, en Agencia Latinoamericana de Información. Disponible en http://alainet.org/ active/52806\&lang=es [Consulta: 30 de noviembre de 2012].

Bordo, Michael y Schwartz, Anna (2001). "From the Exchange Stabilization Fund to the International Monetary Fund", en NBER, documento de trabajo, 8100, enero.

Castells, Manuel (2006). La era de la información. Economía, sociedad y cultura. México, Siglo XXI.

Ceceña, Ana Esther (2012). "Debates que tejen emancipaciones" en Agencia Latinoamericana de Información. Disponible en http://alainet.org/active/55126\&lang=es. [Consulta: 30 de noviembre de 2012].

Chang, Ha-Joon (2004) Retirar la escalera. La estrategia del desarrollo en perspectiva histórica, Madrid, Catarata.

Chang, Ha-Joon y Grabel, Ilene (2006) "Mitos y realidades acerca del desarrollo" en Reivindicar el desarrollo. Un manual de política económica alternativa. Barcelona, Intermón Oxfam, pp. 21-59.

Conferencia de las Naciones Unidas sobre Comercio y Desarrollo (UNCTAD) (2011). Acontecimientos recientes en los principales mercados de productos básicos: tendencias y desafíos, noviembre 9 [en línea]. Disponible en http://unctad.org/es/docs/cimem2d19_sp.pdf [Consultado: 30 de noviembre de 2012].

Davids, Mike (2004). Planetas de ciudades-miseria: involución urbana y proletariado informal. Disponible en http:// 
es.scribd.com/doc/16190752/Davis-Mike-Planetade-ciudades-miseria-NLR-n-26-2004. [Consulta: 30 de diciembre de 2012].

Draghi, Mario (2011). The euro, monetary policy and the design of a fiscal compact. Informe presentado en Berlín: Ludwig Erhard Lecture. Disponible en http://www. ecb.int/press/key/date/2011/html/sp111215.en.html [Consultado: 30 de noviembre de 2012].

Duménil, Gérard y Dominique Lévy (2002). "Salida de crisis. Amenazas de crisis y nuevo capitalismo" en Chesnais, F., Dúmenil, G., Lévy, D. e I. Wallerstein La globalización y sus crisis. Interpretaciones desde la economía crítica. Madrid, Catarata, pp. 13-41.

Eisenhower, Dwight (1961). "Military-Industrial Complex Farewell Speech", Public Papers of the Presidents, Dwight D. Eisenhower, 1960, pp. 1035-1040. Disponible en http://coursesa.matrix.msu.edu/ hst306/documents/indust.html. [Consulta: 08 de febrero de 2013]. Elwell, Craig K. (2011), "Brief History of the Gold Standard in the United States" en Congressional Research Service, 7-5700, R41887. Disponible en http://www.fas.org/sgp/crs/ misc/R41887.pdf. [Consulta: 08 de febrero de 2013].

Esquivel, Valeria (2011). La economía del cuidado en América Latina: poniendo a los cuidados en el centro de la agenda, El Salvador, PNUD, Área y práctica de género.

Fals Borda, Orlando (2009). Una sociología sentipensante para América Latina. Bogotá: Clacso y Siglo del Hombre Editores.

Foucault, Michel (1988). "El sujeto y el poder" en Revista Mexicana de Sociología, vol. 50, núm. 3, julio-septiembre, pp. 3-20. 
(1999) “¿Qué es la ilustración?" [Was ist Aufklärung?]

en Obras esenciales vol. III, Michel Foucault. Estética, ética y hermenéutica. Barcelona, Paidós, pp. 335-352.

Garber, Peter (1991) "The Collapse of the Bretton Woods Fixed Exchange Rate System", en Bordo, M. y B. Eichengreen. A Retrospective on the Bretton Woods System: Lessons for International Monetary Reform, University of Chicago Press.

Guillot, Gustavo Duch (2012). El ABCD de la crisis alimentaria.

Disponible en http://alainet.org/active/59631\&lang=es [Consulta: 12 de diciembre de 2012].

Gunder Frank, Andrés (1967), “El desarrollo del subdesarroIlo", Pensamiento Crítico, La Habana, agosto de 1967, núm. 7, pp. 159-173.

Harvey, David (2004) "El nuevo imperialismo. Acumulación por desposesión" en Socialist Register, Buenos Aires, Clacso, pp. 99- 129.

Hurd, Michel D. y Rohwedder, Sussan (2010). "Effects of the financial crisis and great recession on American Households" en NBER, documento de trabajo num. 16, 407. Cambrigde, septiembre. Disponible en http://www. nber.org/papers/w16407.pdf?new_window $=1$ [Consulta: 30 de noviembre de 2012].

Kant, Emmanuel (2009) "Qué es la ilustración" en Filosofía de la Historia. Madrid, Fondo de Cultura Económica, pp. 25-37.

Klein, Naomi (2010). “Las resistencias a la doctrina del shock en América Latina" en León, I. (comp.) Sumak Kawsay/ Buen vivir y cambios civilizatorios. Quito, Editorial FEDAEPS. 
Lapavitsas, Costas (2011). "El capitalismo financiarizado. Crisis y expropiación financiera" en Lapavitsas, C. (comp.) La crisis de la financiarización. México, IIEC UNAM, Consejo Latinoamericano de Ciencias Sociales, pp. 33-90.

Lara Cortés, Claudio (2009). "Una crisis global inédita: el rol financiero de los Estados nacionales" en Gudynas, E. (comp.). La primera crisis global del siglo xxl: miradas y reflexiones. Montevideo, Clases y desarrollo, economía, ecología y equidad, pp. 8-10.

Mandel, Ernest (1974), La recesión generalizada, México, Editorial Transición, 1974/1979.

Marichal, Carlos (2010). Nueva historia de las grandes crisis financieras: una perspectiva global, 1873-2008. BarceIona, Debate.

McGuire, Patrick y Goetz von Peter (2009). "The US dollar shortage in global banking" en BIS Quartely Review, marzo. Disponible en http://www.bis.org/publ/ qtrpdf/r_qt0903f.pdf [Consultado: 30 de noviembre de 2012].

Morera, Carlos y José Antonio Rojas (2011). "La globalización del capital financiero 1997-2008" en Lapavitsas, C. (comp.). La crisis de la financiarización, México, IIEC unam, Consejo Latinoamericano de Ciencias Sociales, pp. 271-308.

Nölke, Andreas (2011), "Transnational Economic Order and National Economic Institutions. Comparative Capitalism meets International Political Economy" en MPIFG documentos de trabajo 11/3, Max Planck Institut Für Gesellschaftforschung, abril.

Palma, Gabriel (2009). "The revenge of the market on the rentiers: Why neo-liberal reports of the end of history 
turned out to be premature" en Cambridge Journal of Economics, 829-869, 33(4).

Pérez, Carlota (2004). Revoluciones tecnológicas y capital financiero: la dinámica de las grandes burbujas financieras y las épocas de bonanza, México, Siglo XXI.

Prebisch, Raúl (1996). "El desarrollo económico de América Latina y algunos de sus principales problemas" en Trimestre Económico, núm. 249, México, Fondo de Cultura Económica.

Quijano, Aníbal (2010). "América Latina: hacia un nuevo sentido histórico" en León, I. (comp.) Sumak Kawsay/ Buen vivir y cambios civilizatorios. Quito, Editorial FEDAEPS, pp. 55-72.

Razavi, Shahra (2007). The political and social economy of care in a development context. United Nations Research Institute of Social Development. Disponible en http:// www.unrisd.org/80256B3C005BCCF9/(httpPublicatio ns)/2DBE6A93350A7783C12573240036D5A0?OpenD ocument [Consulta: 30 de noviembre de 2012].

Robinson, William (2011). "Crisis estructural y rebelión popular transnacional" en Revista América Latina en movimiento. "De indignaciones y alternativas". Quito, FEDAEPS Y ALAI, 1-4.

Sandoval, Luis (2004). Los ciclos económicos largos Kondratiev y el momento actual. Disponible en http://www. ucm.es/info/ec/jec9/pdf/A07\%20\%20Sandoval\%20 Ram\%EDrez,\%20Luis.pdf [Consulta: 30 de noviembre de 2012].

Santos, Boaventura de Sousa (2009). Una epistemología del sur, México, Siglo XXI y Consejo Latinoamericano de Ciencias Sociales. 
(2010). "La hora de los invisibles" en León, I. (comp.)

Sumak Kawsay/ Buen vivir y cambios civilizatorios, Quito, Editorial FEDAEPS, pp. 11-25.

Santos, Boaventura de Sousa y Rodríguez, César (2012). "Para ampliar el canon de la producción" en Santos, B. De las dualidades a las ecologías. Bolivia, Red Boliviana de Mujeres Transformando la Economía.

Sassen, Saskia (2013). "Drones over there, total surveillance over here", febrero, 19. Disponible en http://www.aljazeera. com/indepth/opinion/2013/02/2013210114231346318. html [Consulta: 12 de marzo de 2013].

Schuldt, Jürgen (2011). Trasfondo estructural y sociopolítico de la crisis estadounidense, Lima, Universidad del Pacífico. Shaxson, Nicholas (2012), Treasure Islands: Tax Havens and the men who stole the world, Londres, Vintage. |

Stiglitz, Joseph (2010), The Stiglitz Report: Reforming the International Monetary and Financial Systems in the Wake of the Global Crisis, Nueva York, New Press.

Ugarteche, Óscar (2012a). "Las paradojas de la crisis del capitalismo actual" en Revista Ideele, marzo. Disponible en: http://www.revistaideele.com/ideele/content/ las-paradojas-de-la-crisis-del-capitalismo-global [Consulta: 30 de noviembre de 2012].

(2012b). "The Modern Bussines of War", en Sen, G. y M.

Durano (comp.) Sin título, Londres, Zedbooks, en prensa. Villarán, Fernando (2012). La picadura del escorpión, Lima, Ed. Planeta.

Vos, Jan de (2012). “Un papa aferrado a la metafísica platónica"en La Jornada, marzo, 3. Disponible en http://www. jornada.unam.mx/2013/03/03/opinion/022a1mun [Consulta: 12 de marzo de 2013]. 
Whitehouse, Edward (2010). "Pensions during the crisis: Impact on retirement-income systems and policy responses" en Social Policy Division, OECD. Disponible en http://www.ica2010.com/docs/240_final_paper_ Whitehouse.pdf [Consulta: 30 de noviembre de 2012]. Williamson, John (1990). "Latin American Adjustment. How Much has happened?" en Institute of International Economics, Washington D.C.

Zemelman, Hugo (2004). "Pensar teórico y pensar epistémico. Los desafíos de la historicidad en el conocimiento social", en Sánchez Ramos, I. y Sosa Elízaga, R. (comp.) América Latina: los desafíos del pensamiento crítico. México, Siglo XXI. 
LA GRAN MUTACIÓN. El capitalismo real del siglo XXI, es un libro del Instituto de Investigaciones Económicas de la Universidad Nacional Autónoma de México. Se terminó de imprimir el 27 de julio 2013. Se tiraron 500 ejemplares en impresión offset en los talleres de Fuentes Impresores, Centeno 109, colonia Granjas Esmeralda, delegación Iztapalapa, 09810 México, Distrito Federal. La formación tipográfica estuvo a cargo de Carlos José Bravo Nieto; se utilizó la fuente Myriad Pro de 8, 9, 10 y 11 puntos. El cuidado de la edición estuvo a cargo de Hélida De Sales Y. 